\title{
Green shipping onboard: acceptance, diffusion \& adoption of LNG and electricity as alternative fuels in Greece
}

\author{
Olga Sideri ${ }^{*}$ (D), Michalis Papoutsidakis ${ }^{1}$, Theodore Lilas $^{2}$, Nikitas Nikitakos ${ }^{2}$ and Dimitrios Papachristos ${ }^{1}$
}

\author{
*Correspondence: olga_sid_@ \\ hotmail.com \\ ${ }^{1}$ University of West Attica, Egaleo \\ 12241, Greece \\ Full list of author information is \\ available at the end of the article
}

\begin{abstract}
Today, alternative fuels are seen as a critical area of sustainable technological growth in maritime transport. The International Maritime Organisation (IMO), the United Nations body for maritime issues and other international bodies are in the process of amending and updating the regulations applicable to the shipping industry. Greece is ready to enter the era of liquefied natural gas $(L N G)$ and electricity as marine fuels, as Eastern Mediterranean projects are heading towards adopting these alternative fuels. This study aims to explore the intention of the Greek stakeholders in accepting and using LNG and electricity as alternative fuels. The research objectives are to identify, analyse and evaluate the determinants that influence the intention to accept, diffuse and use alternative fuels, LNG and electricity for marine propulsion, and develop, construct and validate a hybrid model that can be used for future study. This research will clarify possible challenges or barriers to the implementation of technology by stakeholders and contribute to a deeper understanding of the green shipping network. It will also highlight the role of key players in the diffusion phase of technological innovation and the technology itself and its characteristics. Moreover, this research will suggest a unified model using the expansive Technology Acceptance Model (TAM) in conjunction with the Innovation Diffusion Theory (IDT) and external variables affecting $L N G$ and electricity 1 ) to investigate the intent of implementing the use of such alternative fuels and 2) to inform policymakers concerning sustainable shipping.
\end{abstract}

Keywords: Technology acceptance model (TAM), Innovation diffusion theory (IDT), Liquefied natural gas (LNG), Electricity

\section{Introduction}

Alternative fuels have received considerable attention in recent years. Alternative fuel penetration in shipping is largely motivated by the need to reduce greenhouse gases (GHG) emissions (Paris Agreement) and to comply with the more stringent sulfur emission requirements of Annex VI to the MARPOL treaty of the IMO. Known as 'IMO 2020', the reduced limit is mandatory for all ships operating beyond some designated emission control areas (ECAs) where the limit is already $0.10 \%$ (International Maritime Organization (IMO), n.d.). Furthermore, the MARPOL treaty establishes PM

(c) The Author(s). 2021 Open Access This article is licensed under a Creative Commons Attribution 4.0 International License, which permits use, sharing, adaptation, distribution and reproduction in any medium or format, as long as you give appropriate credit to the original author(s) and the source, provide a link to the Creative Commons licence, and indicate if changes were made. The images or other third party material in this article are included in the article's Creative Commons licence, unless indicated otherwise in a credit line to the material. If material is not included in the article's Creative Commons licence and your intended use is not permitted by statutory regulation or exceeds the permitted use, you will need to obtain permission directly from the copyright holder. To view a copy of this licence, visit http://creativecommons.org/licenses/by/4.0/. 
limits and limits on the NOx emissions from marine diesel engines to address the requirements for preventing air pollution from ships. These regulations mean that an estimated $70 \%$ of the fuels currently used by the sector need to be modified or changed (European Alternative Fuels Observatory (EAFO), n.d.).

The use of alternative fuels is now seen as a crucial area in the technological transition to sustainable shipping. Shipping is the backbone of international trade, with about $80 \%$ of world trade in goods being traded by the global shipping industry (ECSA, 2017). Although shipping has the lowest environmental footprint in the transport sector, considering the large share of shipping in the global transport industry, the gradual integration of alternative fuels by shipping would have a substantially positive environmental impact.

Several solutions are being assessed. However, this research investigates and evaluates the intention to accept and use LNG and electricity as alternative fuels for Greece's marine propulsion. The shipping industry has recently been developing strategies and projects to adopt and integrate these alternative fuels. The projects were supported and co-financed in their initial stages by the Connecting Europe Facility (CEF) of the European Union (EU) and other funding under the stakeholders' umbrella in the shipping industry.

The starting point was in 2014 with the COSTA project (2011-EU-21007-S) aimed at developing framework requirements for the use of LNG for ships in the Mediterranean, Atlantic and the Black Sea regions (European Commission) and, subsequently, the direct continuation of COSTA II East Sea (Poseidon Med). This project, part of TEN-T Priority Project 21, concerned the preparation and introduction of a global strategy for the Eastern Mediterranean so that LNG could be used as a marine fuel for international shipping (European Commission). The next phase was the launch in 2015 of Poseidon Med II (completed in 2020) which involved three countries Greece, Italy and Cyprus and aimed to make the LNG bunkering infrastructure a reality for all participating ports ((Piraeus, Patras, Limassol, Venice, Heraklion, Igoumenitsa) as well as the Revithoussa LNG terminal.

Concerning electricity, the Elemed project, launched in 2016, prepares the ground for the introduction of cold ironing, electric bunkering and hybrid ships throughout the Eastern Mediterranean Sea corridor and establishes an action plan for three countries - Greece, Cyprus and Slovenia - and four ports - Piraeus, Limassol, Koper and Killini - for the eventual transition to a zero-emission marine transportation era. This project highlights the value of electricity for the accomplishment of future decarbonisation scenarios.

These alternative fuels offer enormous opportunities for a sustainable transition to a 'green shipping' and, thus, the policy agendas for sustainable development are key to alternative fuels. Both technologies already comply with stringent ship pollution regulations. The purpose of this paper is to provide an overview of both technologies in the making with the stakeholders' engagement to be crucial for the intention to adopt them as marine fuels in Greece. The study also attempts to develop a theoretical model to identify, analyse, and evaluate the key factors that affect and contribute to the acceptance and usage of these alternative fuels.

To date, no corresponding study has been found that empirically examines the intention to accept and use LNG and electricity, nor have the two models of 
technological acceptance been used to analyse maritime technologies. We consider this to be the first research to investigate empirically the behavioural intent of accepting and using LNG and electricity to promote sustainable shipping. Since these technologies are in the early stages of development, consumer behaviour cannot be calculated directly. However, we should calculate the behavioural intent of future users who would implement such technologies to achieve the forecast of actual usage.

\section{Theoretical background}

Throughout the years, various theories and models (Theory of Reasoned Action Fishbein and Ajzen,, 1975; Theory of Planned Behaviour - Ajzen, 1985; Social Cognitive Theory - Bandura, 1986; The Model of PC Utilization - Thompson et al., 1991; The Motivation Model - Davis et al., 1992; TAM2 (Extended TAM2 model) - Venkatesh and Davis, 2000); Theory of Acceptance and Use of Technology (UTAUT) Venkatesh et al.; 2003; Model of Acceptance with Peer Support (MAPS) - Sykes et al., 2009) have been developed to identify the factors that play a crucial role in the acceptance and adoption by users of new technologies.

Technology acceptance theories and models aim to convey the meaning of how users understand and accept new technologies and how they can use them (Momani and Jamous, 2017). All technology acceptance theories are designed to assess the degree of the acceptance of technologies by individuals. These technology acceptance theories differ in terms of their structure (different points of view) and the variables/constructs that support them. For any emerging technology, there are several factors that influence the decision-making process of individuals on how they can use it.

In this scope, two theories developed to explain the acceptance of LNG and electricity by Greek stakeholders are the Technology Acceptance Model (TAM) and the Innovation Diffusion Theory (IDT), which will be discussed below. Many empiric studies recommend the integration of TAM with other theories to address rapid technological change and improve specialisation and explanatory power (Carter and Belanger, 2005, Legris et al., 2003).

The TAM model provides feedback on two factors, utility and ease of use, but does not explicitly include any social variables that may enhance adoption, nor does it show how the constructions are related. Conversely, the IDT theory explains the adoption of innovation, but does not state how attitudes affect the acceptance or rejection of decisions. Therefore, with this unified model, we will have a more powerful tool for assessing the acceptance of technology, as the TAM model is often criticised that it does not include social features and that this information is not considered sufficient in the process of technology adoption.

Furthermore, new constructs will be applied to this combined theoretical model, which will lead to a better assessment of particular technologies. These constructs are known as external variables (e.g., system characteristics), which are considered in the TAM model in conjunction with the concepts advocated by the innovation diffusion theory.

To date, several studies have successfully incorporated IDT into TAM to examine the acceptance of technology by users and have shown good results through the integration of these two models (Sigala et al., 2000, Wu and Wang, 2005, Chang and Tung, 2008). Subsequent studies, therefore, incorporate the two theories but without integrating and 
examining all the characteristics of innovation as determining factors in the acceptance of technology (Lou and Li, 2017).

In this research, we improve the TAM model by combining all the IDT features so that they can be treated as external variables that directly affect the design of the technology acceptance model. By introducing multiple selected external variables to the two innovative technologies that are the subject of the current study, we increase the reliability and effectiveness of the research. The two models of technological acceptance will be analysed below.

\section{Technology acceptance model}

The Technology Acceptance Model (TAM) is one of the most widely used theories in information system (IS) research. The TAM model was developed by F. D. Davis in 1989, and is one of the most popular and influential theories for predicting the acceptance and use of technology by end-users. TAM relies on the theory of reasoned action (Fishbein and Ajzen, 1975) and argues that two variables, perceived ease of use (PEU) and perceived usefulness (PU), can predict the actual use of technology. These two constructs were originally proposed by Davis (1989) with the following definitions: perceived usefulness represents "the degree to which a person believes that using a particular system would enhance his or her job performance" (Davis, 1989), and perceived ease of use represents "the degree to which a person believes that using a particular system would be effortless" (Davis, 1989).

The TAM model is complemented by the concept of Attitude Towards Use, which is the evaluation of the system by the user in terms of the acceptance of Information Technology and the concept of Behavioral Intent to Use, which is a measure of the likelihood that a person will use a particular technology/system. Finally, there is the actual use, which is a dependent variable of the TAM and is determined by the duration or frequency of using the technology. Both variables are relevant to the intention of the acceptance of new technologies.

Research to date has shown the validity of this model, which is now widely accepted. It has become the most widely used and validated model for explaining and predicting accepting behaviours and the intention to use a technology (Sivo et al., 2018). According to Wiley-Patton, TAM's power is attributed to its ubiquitous application (AlGhaith, 2015) as it has been used repeatedly by many scholars for different technologies since it was first introduced and has therefore been widely used for technology adoption in a variety of settings in recent decades.

However, TAM is also a relatively simple model that can be modified or extended in various ways. Therefore, in the literature there are several extensions that include other theories (Lou and Li, 2017). TAM has been the subject of numerous additions and developments, such as the unified theory of the acceptance and use of technology (Venkatesh et al. 2003). Moreover, the two core factors (PU and PEU) are affected by external variables (Surendran, 2012). TAM provides a basis for monitoring how external variables affect belief, attitude and intent to use (Sung, 2009).

In summary, we have chosen the Technology Acceptance Model (TAM) to examine LNG and electricity as marine fuels in Greece, since TAM is a prominent theory in technology acceptance research, it has been implemented in many fields, and the ability 
to expand it with external variables in order to focus on the concerns of these fuels makes it a powerful tool to encourage acceptance, diffusion and adoption of LNG and electricity.

\section{Innovation diffusion theory}

Diffusion of Innovation Theory (IDT) was proposed by Everett Rogers and is one of the most well-known technological innovation theories. It provides an understanding of how innovations are diffused within and between communities (Rogers, 1995). Rogers has developed a framework in which he seeks to identify the factors that explain how and at what rate innovations are spreading, that is, new ideas and technologies. The framework consists of a variety of variables that are linked to the rate of adoption of innovations. Rogers' intention with the model was to discover "how the properties of innovations affect their adoption" (Rogers, 1995).

Accordingly, the IDT theory maintains that "potential users decide to adopt or reject an innovation based on beliefs they form about innovation (Karahanna et al., 1999). In particular, in his book 'Diffusion of Innovations', Rogers defines Innovation as "an idea, a process perceived as new by an individual within a particular field or social context" (Rogers, 2003). On the other hand, the other key term, diffusion, is perceived and defined as "the process by which information about innovation flows from one person to another in the social system through certain channels" (Rogers, 1995).

Rogers' theory recognises five innovation characteristics, namely relative advantage, compatibility, complexity, trialability and observability, which, in turn, affect the pace and the degree of adoption by each member of a social system.

Relative advantage is defined as the degree to which innovation is considered better than the idea that it replaced, and the benefits perceived by the user in implementing the new technology. Essentially, it is the recognition of the relative advantage that this particular innovation offers. The relative advantage can be demonstrated by "economic profitability, social prestige or other benefits" (Rogers, 1995). This construction has been identified as one of the best predictors for the adoption of innovation (Lee et al., 2011).

Compatibility refers to the extent to which innovation is considered to be consistent with the values and habits of existing users, past experience and the needs of potential users (Rogers, 1995). The more compatible an innovation is with a person's lifestyle, the more likely it is to be adopted at a higher rate.

Complexity is defined as the degree to which innovation can be perceived, understood and easily applied to end-users. Complexity is a very important feature as it has been found to have a positive or negative impact on the adoption of technology since it is associated with its ease of use. Less complex innovation is more likely to be accepted by end-users (Tornatzky and Klein, 1982).

Trialability is the possibility of testing, which refers to how innovation can be tested on a limited basis before the decision to adopt it is taken. The test has proved to be an interesting feature of the innovation diffusion model as it enables an individual to "explore" an innovation on their terms before the approval decision is taken. This factor has a positive effect on adoption. 
Observation is defined as the degree to which an innovation's results are visible to other people, that is, the ability to communicate the results of their use. It is also noted that this feature is also said to affect the rate of adoption positively. The easier it is for a person to see the positive effect of innovation, the more likely the rate of adoption and diffusion will increase and the innovation will be approved.

Members of a social system do not adopt an innovation at the same time. Decisions are not collective as each person perceives the innovation process differently. The five factors mentioned above provide the framework for understanding the decision-making process. Rogers (1995) explains that the rate of adoption can be thought of as how quickly innovation is adopted by individuals in a social construct.

Innovation Diffusion Theory has been widely applied in various fields, is still used today, and is the best-known technology innovation theory. Compared with the Technology Acceptance (TAM) model, the diffusion of innovation theory (IDT) is more complete in offering an in-depth conceptual structure on the impact of socio-technical influences on adopting an innovation.

\section{Methodology research}

\section{Research model and hypotheses}

The proposed model of this research is based on Technology Acceptance Model (TAM) integrated with the Innovation Diffusion Theory (IDT) to explore Greek stakeholders' intention to accept and use LNG and electricity as alternative fuels. Furthermore, external variables influencing the use of alternative fuels, specifically LNG and electricity, have been introduced. These variables that define the two alternative fuels are interlinked and have been integrated to make the proposed research model even more reliable and powerful. In order to understand how society can benefit from innovation, it is also important to understand the innovation mechanisms and how they communicate with wider social, institutional and political actors (Fagerberg et al., 2013).

In order to identify the factors that reflect the issues concerning LNG and electricity, a systematic collection of scientific studies and primary sources for both LNG and electricity were conducted to assess the key issues involved in their development in Greece. It is important to clarify that because there is no similar study, the variables were not based on previous research. However, the factors affecting the two technologies' use were identified, constructed, and adapted to the two theoretical models for the first time.

The hybrid model developed, as shown in the Fig. 1, argues that the five innovative features of IDT and key factors affecting LNG and electricity have a major impact on the PU and PEU of TAM and, hence, on the intention to use these alternative fuels. The hybrid model of this analysis represents a potentially unified model to be evaluated and analysed. The arrows that connect the structures (latent variables) determine the hypothesised causal relationship in the arrows' direction. This model will reveal how these various factors influence the acceptance and adoption of LNG and electricity technology in Greece's maritime industry. The validity of the proposed model will be tested based on the following hypotheses. 


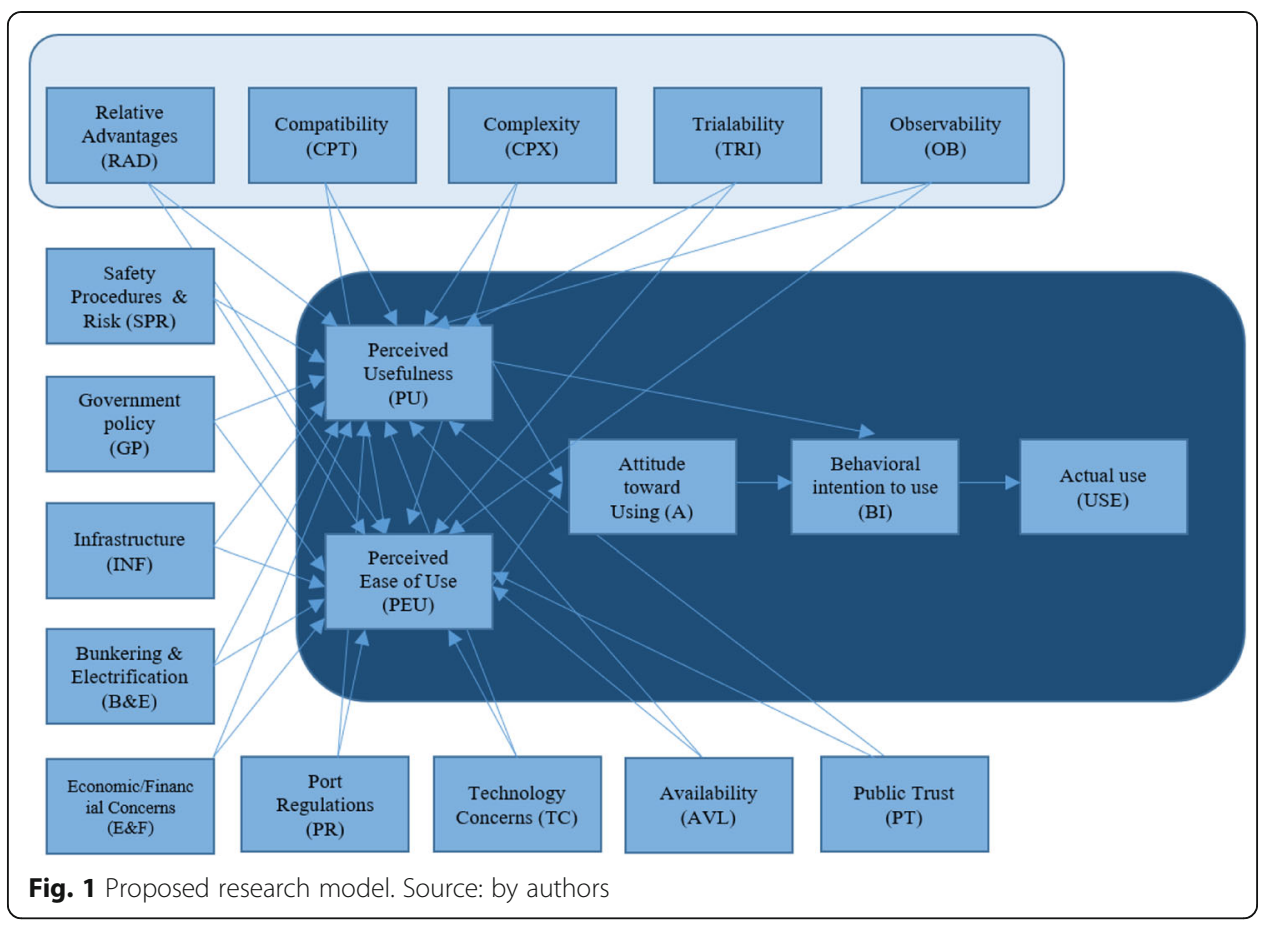

The proposed model was tested with data collected from 50 stakeholders in Greece's shipping industry using a questionnaire. The constructs include 16 items (grouped variables) with 77 issues (Appendix 1). The Google Drive (Forms) service was used to create a questionnaire, and the survey lasted 50 days from September 12, 2019, to October 31, 2019. A common database was then created using Microsoft ${ }^{\circ}$ Excel 2016, which was used to process data through the statistical program SPSS 20. This hybrid model will provide a valuable interdisciplinary framework and background for analysing and assessing factors affecting the technological transition to sustainability.

Therefore, we present the following hypotheses:

\section{Relative advantage (RAD)}

The relative advantage is described as the degree to which innovation is perceived to be better than the idea that has been replaced. Research has consistently shown that perceived relative advantages have had a positive effect on users' intention to apply the system to a variety of participants (Shih, 2007).

H1-1: The relative advantages had a positive effect on the PU of alternative fuels.

H1-2: The relative advantages had a positive effect on the PEU of alternative fuels.

\section{Compatibility (CPT)}

Compatibility involves the degree to which innovation is deemed compatible with current values, prior knowledge and the needs of prospective end-users. Previous studies have shown that compatibility has a significant positive and direct effect on the PU (Chau and Hu, 2001; Wu and Wang, 200; Chang and Tung, 2008). 
H2-1: Compatibility had a positive effect on the PU of alternative fuels.

H2-2: Compatibility had a positive effect on the PEU of alternative fuels.

\section{Complexity (CPX)}

Complexity is the perceived level of difficulty of end-users in understanding innovations and their use. Empirical studies have shown that complexity has a significant adverse effect on the intention to use (Tornatzky and Klein, 1982; Van Slyke et al., 2004).

H3-1: Complexity negatively affected PU of alternative fuels.

H3-2: Complexity negatively affected PEU of alternative fuels.

\section{Trialability (TRI)}

Trialability refers to the degree to which innovations can be tested on a limited basis. One study found that, when users perceived higher testing, they perceived higher levels of technology utility and usability (Yang, 2007).

H4-1: Trialability had a positive effect on the PU of alternative fuels.

H4-2: Trialability had a positive effect on the PEU of alternative fuels.

\section{Observability (OB)}

Observability is the degree to which other people can see the results (effects) of innovations. According to previous research, when staff found systems that could be observed or described more easily, they tended to adopt these systems (Yang, 2007).

H5-1: Observability had a positive effect on the PU of alternative fuels.

H5-2: Observability had a positive effect on the PEU of alternative fuels.

\section{Safety procedures and risk (SPR)}

Safety Procedures and Risk are a detailed description of a process in which a deviation can cause a loss. Risk is the probability that an individual will be harmed or have an adverse health effect if they are exposed to a hazard (Mokhatab et al. 2014, DNV GL, 2014).

H6-1: Safety Procedures and Risk negatively affected the PU of alternative fuels.

H6-2: Safety Procedures and Risk negatively affected the PEU of alternative fuels.

\section{Governance policy (GP)}

Governance Policy refers specifically to the set of rules, controls, policies and resolutions for adopting emerging technologies. Previous research carried out by Verbeek et al. (2011) has shown that policies can have a positive effect on the adoption of alternative fuels.

H7-1: Governance Policy had a positive effect on the PU of alternative fuels.

H7-2: Governance Policy had a positive effect on the PEU of alternative fuels. 


\section{Infrastructure (INF)}

LNG and electricity infrastructure issues concern LNG bunkering and cold ironing. Besides, adjusting ship technology to accommodate the use of natural gas as fuel, LNG bunkering requires the availability of specialised port terminals (small-scale LNG) or mobile LNG supply services (i.e. trucks or barges) (Tzannatos and Nikitakos, 2013). Almost all research studies that investigate these fuels refer to the lack of infrastructure of LNG and electricity networks (Wang, Notteboom, 2014), (DNV GL, 2014).

H8-1: Infrastructure negatively affected the PU of alternative fuels.

H8-2: Infrastructure negatively affected the PEU of alternative fuels.

\section{Bunkering and electrification (B\&E)}

LNG bunkering is the practice of supplying LNG fuel to a ship for its propulsion. Electrification refers to the use of electrical power in the process of a machine or system (Sea-LNG, 2020), (Cleantech Group, 2020).

H9-1: Bunkering and Electrification had a positive effect on the PU of alternative fuels. H9-2: Bunkering and Electrification had a positive effect on the PEU of alternative fuels.

\section{Economic and financial concerns}

The economic viability of alternative fuel strategies and substantial capital investments are the primary issues raised by all stakeholders. (Wang and Notteboom, 2014).

H10-1: Economic and Financial Concerns negatively affected the PU of alternative fuels.

H10-2: Economic and Financial Concerns negatively affected the PEU of alternative fuels.

\section{Port regulations (PR)}

The role of ports in the bibliography is limited. However, the role of ports as a mediator is crucial to the "chicken-and-egg" problem (Wang and Notteboom, 2014).

H11-1: Port Regulations had a positive effect on the PU of alternative fuels.

H11-2: Port Regulations had a positive effect on the PEU of alternative fuels.

\section{Technological concerns (TC)}

While LNG and electricity are promising solutions to sustainable shipping issues, there are technological concerns with their actual implementation (Lee et al, 2017), (DNV GL,2018).

H12-1: Technological Concerns negatively affected the PU of alternative fuels.

H12-2: Technological Concerns negatively affected the PEU of alternative fuels. 


\section{Availability (AVL)}

These emerging technologies, LNG and electricity, must be made available on the market in appropriate quantities. By recognising that LNG and electricity fulfil the shipping industry's requirements, users have seen a higher degree of network efficiency. However, there is uncertainty about this aspect (DNV GL,2018).

H13-1: Availability negatively affected the PU of alternative fuels.

H13-2: Availability negatively affected on the PEU of the alternative fuels.

\section{Public trust (PT)}

As the factors that affect the adoption of LNG and electricity are deemed to promote sustainability or closely related to the stakeholder's needs (because of the IMO legislation), public trust should encourage the integration and adoption of alternative fuels.

H14-1: Public Trust had a positive effect on the PU of alternative fuels.

H14-2: Public Trust had a positive effect on the PEU of alternative fuels.

\section{Perceived utility (PU)}

$\mathrm{PU}$ is the degree to which a person believes that a particular system would improve the performance of his or her work within the organisational framework (Davis 1989). Researchers using TAM claim that PU was valid with respect to people's intention to accept different technologies (Venkatesh and Davis, 2000).

\section{H15-1: PU will have a positive effect on the behavioural intention to use alternative} fuels.

\section{Perceived ease of use (PEU)}

PEU is the degree to which an individual believes that the use of a particular system would be effortless (Davis 1989). Previous studies have shown that PEU has a positive impact on the behavioural intention of end-users.

\section{H15-2: PEU had a positive effect on the PU of the e-learning system.}

\section{Hypotheses testing}

Fifteen constructed hypotheses were examined, and the results are shown in Table 1. Overall, 25 out of 30 hypotheses were confirmed by the data.

\section{Measures}

A specially designed questionnaire was used to measure all the main variables of the research model and to collect data for this study. The questionnaire consisted of three parts. The first part of the questionnaire was to gather basic demographic information from the 'users', such as gender, education level, maritime sector, etc. Part 2 of the questionnaire was based on the constructs of TAM and IDT models and the most relevant variables. The constructs include 16 items (grouped variables) with 77 issues (Appendix 1). Part 3 of the questionnaire aimed at establishing the attitude of interviewees 
Table 1 Structural path analysis result

\begin{tabular}{|c|c|c|c|}
\hline Hypotheses & Path & Direction & Results \\
\hline $\mathrm{H} 1-1$ & $\mathrm{RAD} \rightarrow \mathrm{PU}$ & Positive & Confirmed \\
\hline $\mathrm{H} 1-2$ & $\mathrm{RAD} \rightarrow \mathrm{PEU}$ & Positive & Confirmed \\
\hline $\mathrm{H} 2-1$ & $\mathrm{CPT} \rightarrow \mathrm{PU}$ & Positive & Confirmed \\
\hline $\mathrm{H} 2-2$ & $\mathrm{CPT} \rightarrow \mathrm{PEU}$ & Positive & Confirmed \\
\hline H3-1 & $\mathrm{CPX} \rightarrow \mathrm{PU}$ & Negative & Confirmed \\
\hline $\mathrm{H} 3-2$ & $\mathrm{CPX} \rightarrow \mathrm{PEU}$ & Negative & Confirmed \\
\hline H4-1 & $\mathrm{OB} \rightarrow \mathrm{PU}$ & Positive & Confirmed \\
\hline $\mathrm{H} 4-2$ & $\mathrm{OB} \rightarrow \mathrm{PEU}$ & Positive & Confirmed \\
\hline H5-1 & $\mathrm{TR} \rightarrow \mathrm{PU}$ & Positive & Rejected \\
\hline H5-2 & $\mathrm{TR} \rightarrow \mathrm{PEU}$ & Positive & Confirmed \\
\hline H6-1 & $\mathrm{SPR} \rightarrow \mathrm{PU}$ & Negative & Rejected \\
\hline H6-2 & $\mathrm{SPR} \rightarrow \mathrm{PEU}$ & Negative & Confirmed \\
\hline H7-1 & $\mathrm{GP} \rightarrow \mathrm{PU}$ & Positive & Confirmed \\
\hline H7-2 & $\mathrm{GP} \rightarrow \mathrm{PEU}$ & Positive & Confirmed \\
\hline H8-1 & $\mathrm{INF} \rightarrow \mathrm{PU}$ & Negative & Confirmed \\
\hline $\mathrm{H} 8-2$ & $\mathrm{INF} \rightarrow \mathrm{PEU}$ & Negative & Rejected \\
\hline H9-1 & $\mathrm{B} \& \mathrm{E} \rightarrow \mathrm{PU}$ & Positive & Rejected \\
\hline H9-2 & $\mathrm{B} \& \mathrm{E} \rightarrow \mathrm{PEU}$ & Positive & Rejected \\
\hline H10-1 & $\mathrm{E} \& \mathrm{~F} \rightarrow \mathrm{PU}$ & Negative & Confirmed \\
\hline H10-2 & $\mathrm{E} \& \mathrm{~F} \rightarrow \mathrm{PEU}$ & Negative & Confirmed \\
\hline $\mathrm{H} 11-1$ & $\mathrm{PR} \rightarrow \mathrm{PU}$ & Positive & Confirmed \\
\hline $\mathrm{H} 11-2$ & $\mathrm{PR} \rightarrow \mathrm{PEU}$ & Positive & Confirmed \\
\hline $\mathrm{H} 12-1$ & $\mathrm{TC} \rightarrow \mathrm{PU}$ & Negative & Confirmed \\
\hline $\mathrm{H} 12-2$ & $\mathrm{TC} \rightarrow \mathrm{PEU}$ & Negative & Confirmed \\
\hline H13-1 & $\mathrm{AVL} \rightarrow \mathrm{PU}$ & Negative & Confirmed \\
\hline $\mathrm{H} 13-2$ & $\mathrm{AVL} \rightarrow \mathrm{PEU}$ & Negative & Confirmed \\
\hline H14-1 & $\mathrm{PT} \rightarrow \mathrm{PU}$ & Positive & Confirmed \\
\hline $\mathrm{H} 14-2$ & $\mathrm{PT} \rightarrow \mathrm{PEU}$ & Positive & Confirmed \\
\hline H15-1 & $\mathrm{PU} \rightarrow \mathrm{PEU}$ & Positive & Confirmed \\
\hline H15-2 & $\mathrm{PEU} \rightarrow \mathrm{PU}$ & Positive & Confirmed \\
\hline
\end{tabular}

Source: by authors

concerning innovation, covering seven issues. The questionnaire was based on a 5point Likert-type scale and ranged from 'Strongly Agree' (1) to 'Strongly Disagree' (5) containing almost 5 items for the above.

\section{Data analysis and results}

\section{Respondents demographics profile}

A sample of 50 people, where the percentage of men and women account for $90 \%$ and $10 \%$, respectively, reflects how male-dominated the shipping industry is since only 5 women completed the survey questionnaire. In terms of age, the largest percentage of respondents is concentrated in the age group of 41 to 50 years, with a value of $36 \%$. Respondents in the age group between 51 and 60 years account for $26 \%$ and respondents in the age group between 31 and 40 years of age present a percentage of $24 \%$. 
Individuals whose age falls within the 61 and 70 -year range have a rate of $8 \%$, whereas those between the ages of 71 and above have a rate of $4 \%$. Just $2 \%$ of people are in the first age group, which is people up to 30 years of age. Besides, it has been observed that a very high percentage of respondents (76\%) hold a Master's degree. As regards the shipping sector in which the participants are employed, it is observed that almost $90 \%$ of the sample work in classification societies and shipping companies or are shipowners.

\section{Results and discussion}

The next step in the analysis of the data was to examine the significance of the hypothetical interactions of the research model. Appendix 1 includes the correlations for each grouped variable and displays the corresponding path coefficients for the proposed research model. For ease, the variables that have a major correlation are analysed and highlighted below.

Perceived Utility (PU) was significantly influenced by two exogenous factors to be deriving from Innovation Diffusion Theory: Observation $(\mathrm{OB})(547 P<0.001)$ and Complexity $(\mathrm{CPX})(-569 P<0.001)$ supporting $\mathrm{H} 5-1$ and $\mathrm{H} 3-1$ hypotheses respectively. Specifically,

Observation has a positive impact on the Perceived Utility of the two alternative fuels, LNG and electricity. Appendix 1 presents the results of the correlation between the observability and the PU. All correlations are found to be statistically significant at $1 \%$. The positive impact on the PU is reflected in the fact that participants feel that they should share the effects of the use of LNG and electricity, also that the majority have seen the 'benefits' of the two alternative fuels and, more significantly, it is reflected in the progress made by other shipping professionals. Besides, almost $80 \%$ of the participants assume that alternative LNG fuels and electricity will benefit them.

On the other hand, the Complexity factor has a negative effect on the Perceived Utility of both alternative fuels. Appendix 1 shows the correlations between Complexity and Perceived Utility. It has been reported that four of the five variables have a significant correlation. The results showed that the vast majority of participants, $82 \%$, believe that alternative fuels have a complex fuel supply system. Moreover, complexity shows a negative impact because 1) too many participants conclude that alternative fuels' performance remains low and 2) 54\% of participants 'strongly agree' that the fragmented landscape at decision making at both global and national level has a negative impact of alternative fuels. Eventually, $90 \%$ of the participants agree that the various elements (components) within the system itself would lead to complexity.

The independent variables Safety and Risk Procedures (SPR), (738 $P<0.01)$ and Bunkering and Electrification (B\&E), $(-4.00, P<0.01)$ also have a major effect on the dependent variable Perceived Utility (PU). However, the result was contrary to what we assumed (H6-1 and H9-1) (rejected).

Safety procedures and risk have positively impacted the Perceived Utility of LNG and electricity, contrary to our assumptions. As presented in appendix 1, this variable SPR and the control variable, Perceived Utility, show a strong correlation of $1 \%\left(738^{* *}\right)$. It is found that one relationship is statistically significant at $5 \%$, and the other two are statistically significant at $1 \%$ (Appendix 1). The majority of participants believe that the 
inability to address safety issues in the early stages of development will harm the potential development and use of these alternative fuels. Likewise, a total of $64 \%$ agreed that the use of the two specific fuels poses a potential risk. However, a total of $30 \%$ disagreed with the view mentioned above. The question that divided and identified the most statistically significant correlation was the concern over LNG fuel's extremely low temperatures. However, $66 \%$ of the respondents agree that they would feel safe on ships propelled by such alternative fuels, and almost $92 \%$ of respondents agree that risk identification studies were required.

Similarly, the results showed a negative impact $(-4.00)$ of the Bunkering and Electrification variable on the Perceived Utility of LNG and electricity, contrary to our hypotheses. The correlations are shown in Appendix 1, and it is observed that only one relationship is statistically significant at $1 \%\left(-727^{* *}\right)$. The results showed that the lack of bunkering guidelines divided the participants. $44 \%$, agree with the above assumption, while $46 \%$ completely disagree with this assumption. Additionally, the assumption that an international standard for LNG bunkering should not be established, leading to the division of respondents ( $44 \%$ agreed vs. $42 \%$ disagreed). Concerning electricity, the results have shown that $68 \%$ of the respondents agree that advances in battery technology will give an advantage to future ship applications.

Results also showed that Perceived Utility (PU) was significantly influenced by Technology Challenges (TC) $(-846, P<0.001)$ and Availability (AVL) $(-738, P<0.001)$ supporting Hypotheses H12-1 and H13. - 1, respectively. The highest correlation concerning PU was evident in these two variables.

The technological challenges have a negative impact on the Perceived Utility of the two alternative fuels, LNG and electricity. Appendix 1 displays the correlations between the technological challenges and the control variable, PU. It is found that all relationships are statistically significant at $1 \%$ and, also, all have a very high correlation. The results showed that $76 \%$ of the participants agreed with the technological concern that the platform for the resolution of technical problems was still in its infancy. Furthermore, $84 \%$ of the respondents were concerned about space limitations on ships, such as larger tanks required for LNG storage, and almost half of the respondents (48\%) were concerned about conversions to existing vessels in order to operate with those fuels. Nearly all of the respondents expressed concern with the fuel cell that is still in its initial stages. However, the failure of the two marine fuel development networks is a question that $46 \%$ of the participants fully agreed with, even though there was also a significant percentage $(34 \%)$ who remained neutral on this assumption. It should be noted that, in light of the above issues, there are some concerns that alternative fuels cannot work well and cause problems.

Availability also has a negative impact on the Perceived Utility of the two alternative fuels that we are considering. It is observed (Appendix 1) that all relationships are statistically significant at $1 \%$ and, besides, all have robust correlations. The results revealed that there was no clear picture of the specific variable of availability, as there were conflicting views on issues related to the limited production capacity of LNG and electricity, the gaps in the quality standards for these alternative fuels and the fact that they may have poor stability, or that they would not be available in an adequate quality in the future. Furthermore, 34\% of the sample were concerned about the well-known 
'Chicken and Egg' dilemma, 22\% opposed but also a significant one, in which $28 \%$ did not seem to know the issue and remained neutral, as shown in Fig. 2.

Also, Perceived Utility (PU) was found to be significantly influenced by the Infrastructure, $(-, 686, P<0.001)$ and Economic and Financial Concern variables, $(-, 404, P<$ 0.001 ) supporting hypotheses $\mathrm{H} 8-1$ and $\mathrm{H} 10-1$ respectively.

The issue of Infrastructure shows a significant correlation with a negative effect on the Perceived Utility of LNG and electricity. Appendix 1 presents the findings of the analysis of the relationship between the Infrastructure and the control variable. Three of the five correlations of the infrastructure variable are statistically significant at $1 \%$, and one is statistically significant at $5 \%$. The results of the specific infrastructure variables are of great importance as they demonstrate a high degree of unanimity. Initially, almost all participants (98\%) agree that the lack of infrastructure could pose obstacles to the alternative fuel supply chain, as seen in Fig. 3. About $80 \%$ of the participants 'strongly agree' with this statement. This finding highlights the urgent need for the development of infrastructure. In the same pattern, the results indicate that all participants agreed that there was a need for a specific standardisation of requirements for LNG refuelling facilities, the provision of electrical infrastructure in all types of ports, and a cold ironing infrastructure in terminals.

Besides, the findings indicate that all participants, except one person, agree that there was a need for a common standardisation of the requirements for LNG supply infrastructure. This ratio is statistically important at 5\% (Appendix 1). It should be noted that all participants agree that the electrical infrastructure needs to accommodate all kinds of ports and that the infrastructure for cold ironing at marine terminals (ports) is a wise move. The only issue on which the views vary is whether users will be able to easily refuel their ships. Although a significant percentage (46\%) strongly supported, the assumption, another significant percentage, (34\%), disagreed.

The Economic and Financial Concerns factor also shows a significant correlation with a negative impact on the Perceived Utility of the two marine fuels, LNG and electricity. Appendix 1 presents the investigation results into the relationship between the independent variable (E\&F) and the dependent variable (PU). It is noted that two out of five correlations are statistically significant at $1 \%$ and one is statistically significant at $5 \%$. The results show that most respondents do not know whether or not the usage of alternative fuels will result in financial losses, as shown in the Fig. 4. However, $62 \%$ of the respondents believe that these alternative fuels will provide a positive budget for them.
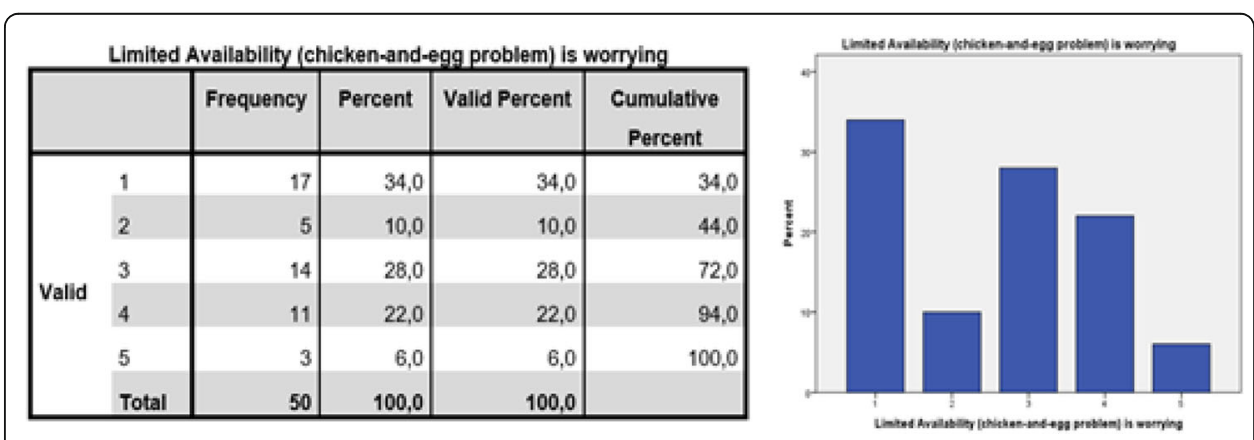

Fig. 2 Limited Availability (the chicken-and-egg dilemma) is worrying. Source: by authors 


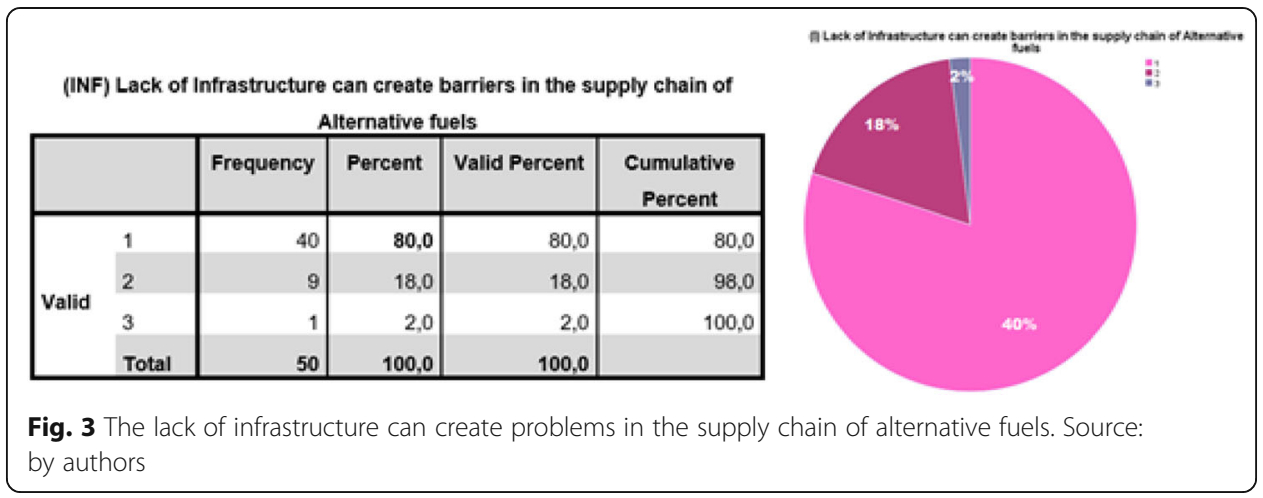

Besides, the majority of participants (78\%) believe that alternative fuels have higher operating costs, $90 \%$ believe that capital costs (for infrastructure, new ships) are huge investments and $68 \%$ believe that the initial investment required (propulsion systems, fuel management systems) is enormous. All these outcomes have resulted in this variable noting a significant correlation with a negative effect.

Compatibility is the only variable found to have a significant correlation on both control variables, Perceived Utility (PU) $(456 p<0.001)$ and Perceived Ease of Use (PEU) (476 $p<0.001)$ confirming cases $\mathrm{H} 2-1$ and $\mathrm{H} 2-2$ respectively. It is observed that there are three statistically significant correlations in Perceived Utility at $1 \%$ and another one statistically significant relationship at 5\% (Appendix 1). The opposite is observed in Perceived Ease of Use, one (1) correlation being statistically significant at $1 \%$ and the other three (3) being statistically significant at 5\% (Appendix 1).

Half of the respondents (50\%) do not know whether or not the use of these two alternative fuels will be compatible with most aspects of their maritime activities. Simultaneously, there is the ambivalence between those who agree and those who disagree, up a $20 \%$ rate for both groups. However, $66 \%$ of the respondents agreed that LNG and electricity would be compatible with their shipping needs. Besides, it is imperative to emphasise that the highest percent of the participants (32\%) respond that they 'strongly agree' that these alternative fuels, LNG and electricity are interoperable with other systems in existing vessels.

According to the TAM, the second dependent variable, Perceived Ease of Use (PEU), was found to be significantly affected by two external factors with a positive effect: the

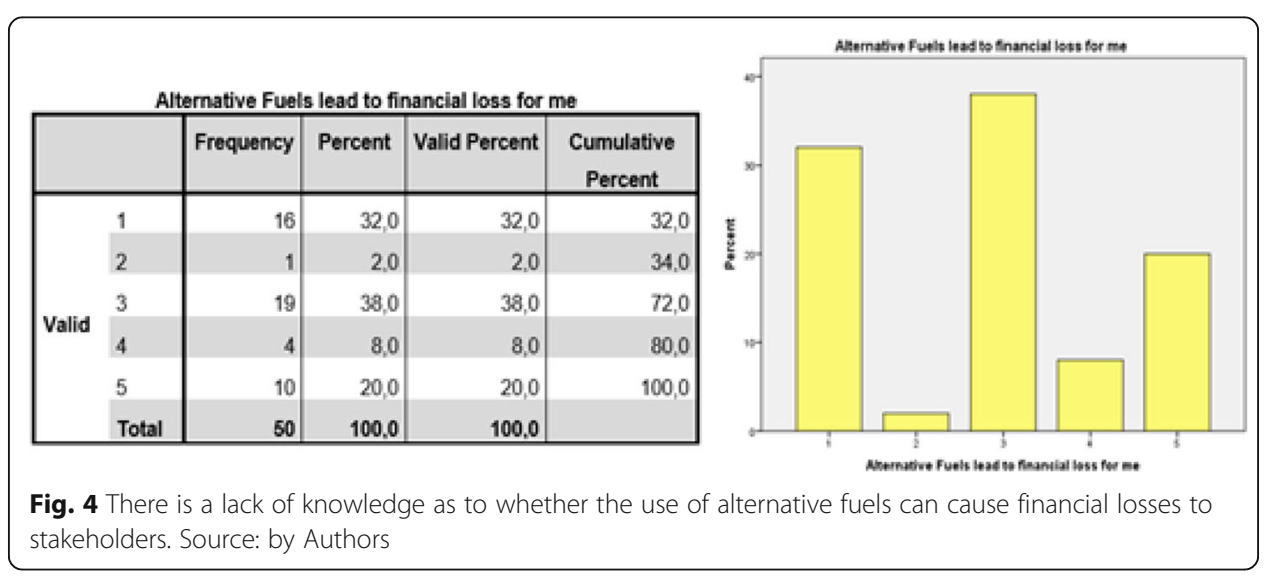


Relative Advantage (RAD) $(613, P<0.001)$ and the Trialability (TR) $(485, P<0.001)$ supporting hypotheses $\mathrm{H} 1-2, \mathrm{H} 4-2$, respectively. These hypotheses have been confirmed.

In particular, the Relative Advantage of these alternative fuels positively impacts the Perceived Ease of Use. The correlations of the independent variable with the control variable are shown in Appendix 1. It is observed that three of the five correlations are statistically significant at $1 \%$. Almost all stakeholders in the shipping industry in Greece consider alternative fuels LNG and electricity to be sustainable (reduce emissions) at a rate of $92 \%$ and provide environmental benefits at a rate of $94 \%$. Subsequently, most participants, 78\%, consider that they are appropriate for the upcoming legislation (International Maritime Organization (IMO), n.d.). Moreover, a significant percentage of the participants, 30\%, consider that LNG and electricity increase energy security. It has also been argued that alternative fuels are reliable, as shown in Fig. 5. These ratios show the superiority of the relative advantage of LNG and electricity over the current technology (MGO).

Trialability, the possibility of trial use, also positively affects the Perceived Ease of Use of both alternative fuels, LNG and electricity. The correlations of the trialability with the control variable can be found in Appendix 1. It is noted that four of the five relationships are statistically significant at $1 \%$. The results showed that most participants believed that a trial would have a significant positive impact on the control variable since it was important before the decision was taken and that specific fuels have accumulated some good testing results abroad. Many stakeholders also agreed that it would be easy for them to find information on the use of the two alternative fuels, as shown in Fig. 5. However, there was a division between stakeholders regarding whether they could withdraw immediately after their use if they are not satisfied. It is observed that the people who agreed together with the people who completely disagreed with this assumption showed the same percentage (38\%).

In addition, the Perceived Ease of Use (PEU) was found to be significantly affected by the positive impact of Governance Policy (GP) $(381, P<0.001)$ and Port Regulations (PR) $(480, P<0.001)$ supporting hypotheses $\mathrm{H} 7-2$ and $\mathrm{H} 11-2$ respectively.

Governance Policy has a positive impact on the Perceived Ease of Use of both alternative fuels, LNG and electricity. Two of the correlations are statistically significant at $1 \%$, and two others are statistically significant at 5\% (Appendix 1). Results have shown that the vast majority of participants $(78 \%)$ believe that integrating and adapting the

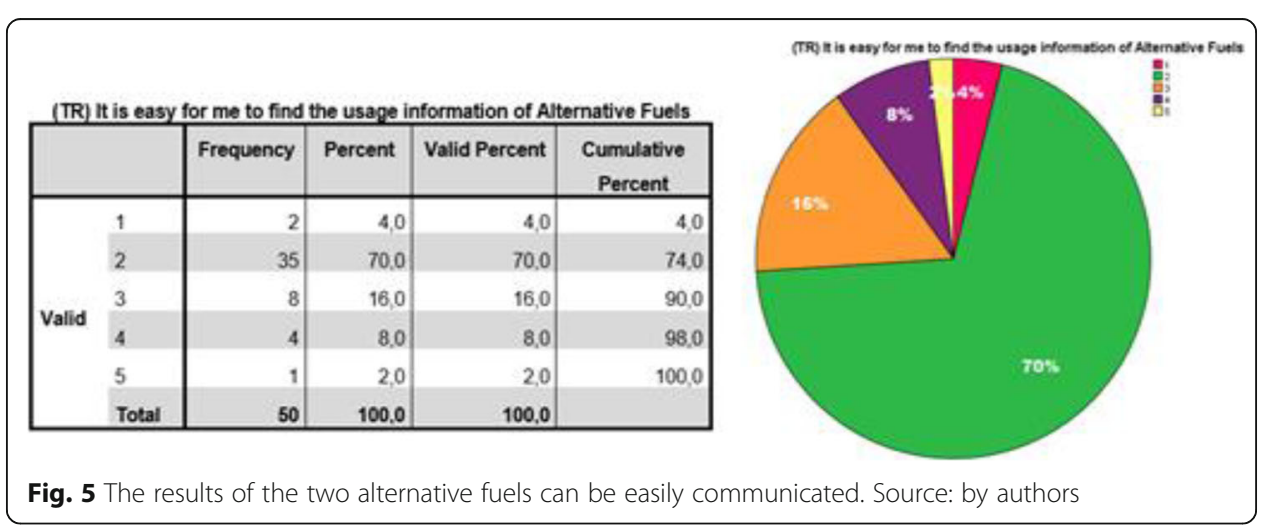


international legal framework for alternative fuels is necessary. Besides, $82 \%$ of respondents agree that a long-term policy framework should favour alternative fuels and that integrated strategies are required to boost alternative fuels usage. Of particular interest is the view of almost all participants (94\%), that policies need to encourage the further improvement of fuels efficiency, as shown in Fig. 6, and that a significant proportion of participants $(78 \%)$ believe that a regulatory timeline towards 2030 is needed.

While the Port Regulations factor is limited to literature, the results show that ports significantly impact the perceived ease of use of both marine fuels as mediators. Two of the relationships are statistically significant, at 1\% (Appendix 1). The results showed that $84 \%$ of the sample stakeholders attach great importance to the role of ports because they agree that ports can lay down rules and address specific operational aspects. The $60 \%$ of participants who 'Strongly agree' that the port authorities should support the deployment of alternative fuels for shipping and 64\% of participants who 'Strongly agree' that alternative fuels should be incorporated by the port authorities are also impressive. Finally, the majority of the participants $(88 \%)$ agree that Port Services should be flexible to interact with the international guidelines of alternative fuels, as seen in Fig. 7.

Finally, concerning the last independent variable, Public Trust, the results have shown that there is no significant impact on public confidence issues in terms of future infrastructure opposition or that there is considerable uncertainty about the use of alternative fuels. Overall, the results show that respondents trust these alternative fuels and are not opposed to their use.

In addition, these results validated the existing research, which, as originally suggested by Davis 1989), established a strong relationship between Perceived Utility and Perceived Ease of Use. The two control factors in the model are considered to be significant factors in determining the acceptance of LNG and electricity as alternative fuels in Greece. Perceived Utility has a positive impact on Perceived Ease of Use and, respectively, the two alternative fuels, LNG and electricity. Appendix 1 presents the results from the investigation of their relationship. We observe that in Perceived Use two of the four relationships are statistically significant at $1 \%$ and one is statistically significant at 5\%. In Perceived Ease of Use, out of the five relationships, one is statistically significant at $1 \%$ and three are statistically significant at $5 \%$.

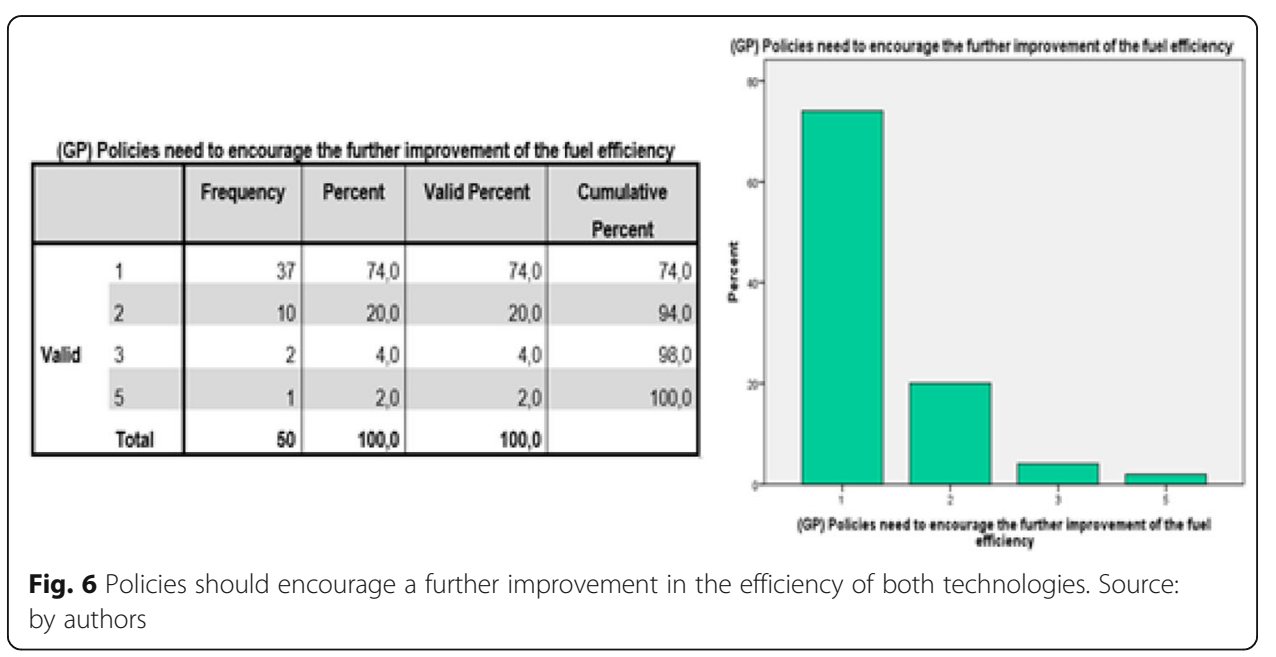


The ratios of the first controlling factor, Perceived Utility, are especially interesting. The overwhelming majority (90\%) disagreed that the development of alternative fuels was a waste of resources. They also responded that the use of alternative fuels would increase the production (38\%), efficiency (34\%) and productivity (42\%) of the company. Overall, as shown in Fig. 8, the majority (30\%) "strongly agreed" that they consider the transition to alternative fuel technology useful.

Results on the issues of Perceived Ease of Use have shown that the majority of participants, with a $56 \%$ percentage of "Absolutely Disagree" that specialization in ships to be supplied with these alternative fuels would be easy and $70 \%$ in total disagreed that it would be easy to acquire the know-how for the use of alternative fuels. A total of $46 \%$ disagreed with the assumption that interaction with alternative fuels does not require mental effort. Nevertheless, it is of particular concern to the majority, $52 \%$, who "strongly agreed" that, overall, they find it useful to embrace alternative fuels, as shown in Fig. 9.

\section{Reliability}

Reliability is a crucial element in the evaluation of the measuring instrument. Reliability concerns an instrument's ability to measure consistently. Cronbach's alpha, the most widely used objective measure of reliability, was computed using SPSS to test the measurement models. The general rule of thumb is that a Cronbach's alpha of 0.7 and above is good. Our result is 0,869 for all of the 84 issues on the questionnaire. This showed that the measurement model exhibited a fairly excellent fit with the collected data. To sum up, the measurement model has achieved very satisfactory levels of reliability, convergent validity and discriminatory validity (see Table 2).

\section{Conclusions}

This paper deals with the transition to alternative fuels in the shipping industry by the use of liquefied natural gas and electricity. The present research aimed to explore the factors associated with using both marine fuels. Specifically, Perceived Utility and Perceived Ease of Use are examined as factors of technological acceptance (control) concerning the five constructs of technology diffusion theory and independent variables reflecting LNG and electricity characteristics.

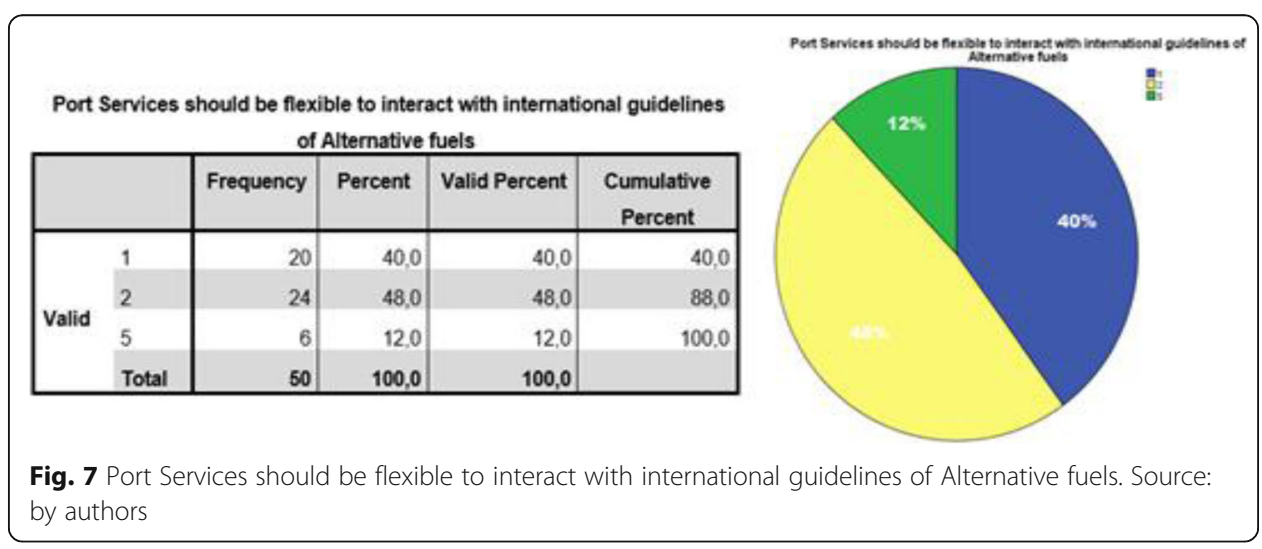




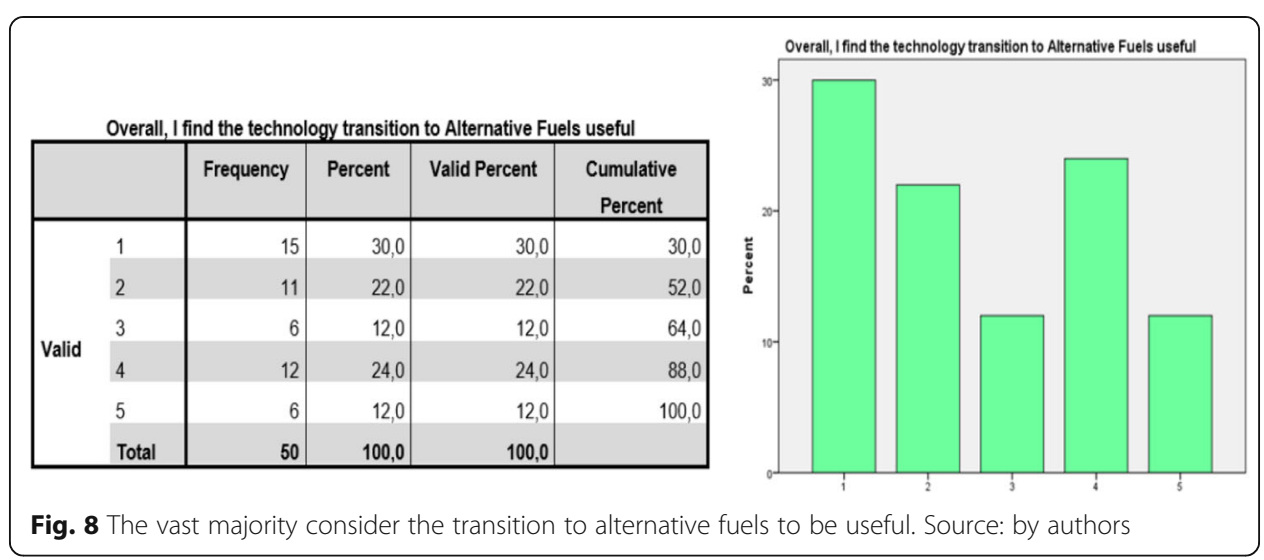

Our study concludes that the results have confirmed the research model and the hypotheses. The two control factors, Perceived Utility and Perceived Ease of Use, are important factors that affect the individual's attitude towards alternative fuels. We found that all the grouped variables had a significant correlation, except for one independent variable, Public Trust. This follows that there is a strong correlation between the variables involved in our study.

Perceived utility has been shown to have the most significant positive correlation in safety and risk processes, suggesting that the more secure users feel with technology, the more willing they are to use it. The most negative correlation is the technological challenges, which indicate that the perceived technological difficulties in adjusting to the new technology may lead to a negative perception of the technology's usefulness.

Perceived Ease of Use is also an essential factor influencing a person's attitude towards the two alternative fuels. The perceived ease of use of LNG and electricity technologies has shown the most significant correlation in the relevant advantage, indicating that it is easier to recognise the new technology's relative advantage. It is noted that there is no negative relationship with Perceived Ease of Use.

Among the innovation diffusion variables, Observation, i.e., the likelihood of evaluating the use of innovation before implementing it, showed a strong positive correlation with Perceived Utility, suggesting that the rate of innovation and diffusion increases when stakeholders can see the beneficial impact of using innovation. Complexity, on the other hand, shows a strong negative correlation with Perceived Value, suggesting that the more complicated and difficult the implementation of technology is, the slower the rate of acceptance. Trialability suggests that the probability of partial testing before the acceptance decision would result in a higher technology adoption rate. The relevant advantage of LNG and electricity also shows a significant positive correlation with the perceived ease of use and, in fact, the most statistically significant correlation. Finally, compatibility is the only factor in the entire research model that has shown a statistically significant positive correlation between the two control factors, indicating that the

Table 2 Cronbach's Alpha

\begin{tabular}{ll}
\hline Reliability Statistics & N of Items \\
\hline Cronbach's Alpha & 84 \\
\hline 0.869 &
\end{tabular}




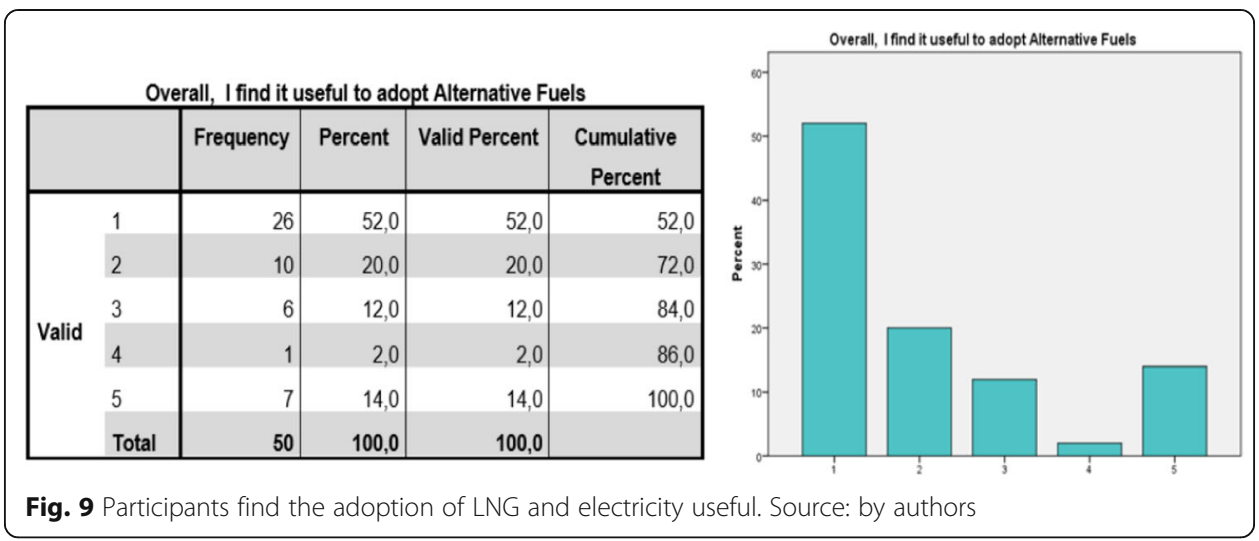

rate of adoption increases when the innovative technology is compatible with existing values and habits.

The following paragraphs show important conclusions drawn from the factors relating to LNG and electricity acceptance and use.

According to the vast majority of participants, the greatest obstacle to the adoption and integration of the two alternative fuels by stakeholders in Greece is the lack of infrastructure. On the same scale, the findings showed problems concerning the two alternative fuels as they have a complex refuelling system. Also, there are problems concerning the system itself, along with its various components, must be integrated and functioning well.

Within the same context, it was especially emphasised that there was a need for a specific standardisation of requirements for LNG supply facilities to provide electrical infrastructure in all types of ports and cold ironing infrastructure in terminals. Standardisation is a complex and demanding process. However, the ship must be refuelled with the same fuel, with the same procedures, with the same conditions, with the same standards. Besides, participants argued that, in order to increase their rate of adoption, a long-term policy framework should favour alternative fuels and that comprehensive strategies are required to secure the use of alternative fuels.

The findings also showed that there was considerable confusion, ignorance or, in general, hostility, it was in the economic and financial parameters. Furthermore, although the Port Authorities' role has been sidelined in international literature, the results contradict it because the role of the Port Authority as a 'Mediator' is of great importance, and the respondents believe that Port Authorities should be flexible to interact with international alternative fuel guidelines.

Stakeholders' strong response to LNG and electricity as alternative propulsion fuels have been established because they can recognise the benefits of using them. They are sustainable, reliable, and well-collected outcomes from their use abroad.

Some general conclusions on the two technologies of LNG and electricity are that legislation aimed at stricter sulfur limits is the driving force behind LNG and electricity promotion. Alternative fuels are emerging from international environmental pressures and are the result of political decisions.

LNG, like electricity at a slower rate, is becoming more popular as a marine fuel. It can be seen that the European projects underway with a view to their adoption, the mass publication of scientific studies, public consultations, and the contribution of the 
press have a vital role to play. European maritime policy implements promotional programs and synergies from stakeholders are needed to develop their use.

As the results have shown, stakeholders intend to use LNG and electricity in the future. However, they do not intend to proceed with immediate planning at this time. The market is in constant transition, and the global market is growing as there are multiple orders for ships fueled by LNG and electricity.

Greece is ready to enter the era of LNG and electricity - or even better - is already transitioning to sustainable shipping. It is expected that their demand as alternative fuels will increase in the coming years; however, there is uncertainty about the pace and scale of demand growth.

It remains for Greece to take advantage of its leading role in the shipping sector to eventually become an international base for the refueling of ships supplied with LNG and electricity in the Eastern Mediterranean and a paradigm for achieving the objectives of sustainable shipping.

\section{APPENDIX 1 - CORRELATIONS}

\begin{tabular}{|c|c|c|c|}
\hline \multicolumn{4}{|l|}{ Correlations } \\
\hline & & PU & PEU \\
\hline \multirow[t]{2}{*}{ RAD } & $\begin{array}{l}\text { Pearson } \\
\text { Correlation }\end{array}$ & 0.058 & $0.613 * *$ \\
\hline & Sig. (2-tailed) & 0.689 & 0.000 \\
\hline \multirow[t]{2}{*}{ (RA) Alternative Fuels are sustainable (reduce emissions) } & $\begin{array}{l}\text { Pearson } \\
\text { Correlation }\end{array}$ & -0.211 & 0.103 \\
\hline & Sig. (2-tailed) & 0.141 & 0.477 \\
\hline \multirow[t]{2}{*}{$\begin{array}{l}\text { (RA) Alternative Fuels are suitable for upcoming legislation (International } \\
\text { Maritime Organization (IMO), n.d.) }\end{array}$} & $\begin{array}{l}\text { Pearson } \\
\text { Correlation }\end{array}$ & 0.315 & $0.511^{* *}$ \\
\hline & Sig. (2-tailed) & 0.026 & 0.000 \\
\hline \multirow[t]{2}{*}{ (RA) Alternative Fuels offer enviromental benefits } & $\begin{array}{l}\text { Pearson } \\
\text { Correlation }\end{array}$ & -0.073 & 0.127 \\
\hline & Sig. (2-tailed) & 0.614 & 0.379 \\
\hline \multirow[t]{2}{*}{ (RA) It is asserted that alternative fuels are reliable } & $\begin{array}{l}\text { Pearson } \\
\text { Correlation }\end{array}$ & 0.394 & $0.864^{* *}$ \\
\hline & Sig. (2-tailed) & 0.005 & 0.000 \\
\hline \multirow[t]{2}{*}{ (RA) Alternative Fuels increases energy security } & $\begin{array}{l}\text { Pearson } \\
\text { Correlation }\end{array}$ & -0.341 & $0.460^{* *}$ \\
\hline & Sig. (2-tailed) & 0.015 & 0.001 \\
\hline \multirow[t]{2}{*}{ TR } & $\begin{array}{l}\text { Pearson } \\
\text { Correlation }\end{array}$ & -0.221 & $0.485^{* *}$ \\
\hline & Sig. (2-tailed) & 0.122 & 0.000 \\
\hline \multirow[t]{2}{*}{$\begin{array}{l}\text { (TR) A trial would convince me that using Alternative Fuels are better than } \\
\text { other }\end{array}$} & $\begin{array}{l}\text { Pearson } \\
\text { Correlation }\end{array}$ & -0.487 & 0.085 \\
\hline & Sig. (2-tailed) & 0.000 & 0.559 \\
\hline \multirow[t]{2}{*}{ (TR) It is easy for me to find the usage information of Alternative Fuels } & $\begin{array}{l}\text { Pearson } \\
\text { Correlation }\end{array}$ & 0.131 & $0.367^{* *}$ \\
\hline & Sig. (2-tailed) & 0.366 & 0.009 \\
\hline \multirow[t]{2}{*}{ (TR) I can try any kind of function before using Alternative Fuels officially } & $\begin{array}{l}\text { Pearson } \\
\text { Correlation }\end{array}$ & -0.337 & $0.394 * *$ \\
\hline & Sig. (2-tailed) & 0.017 & 0.005 \\
\hline (TR) I can quit it if I am not satisfited after trying Alternative Fuels & Pearson & -0.207 & $0.488^{* *}$ \\
\hline
\end{tabular}


APPENDIX 1 - CORRELATIONS (Continued)

\section{Correlations}

(TR) Alternative Fuels have accumulated some good testing results
OB
(OB) I could have many opportunities to discuss the usage of Alternative
Fuels

(OB) I have seen the application of Alternative Fuels

(OB) I have seen my coworkers using Alternative Fuels

(OB) I can easily feel that Alternative Fuels could bring me some benefits

(OB) I have seen the demonstrations of Alternative Fuels

CPT

(CPT) Using Alternative Fuels would be compatible with the most aspects of my Maritime Activities

Correlation

PU

PEU

Sig. (2-tailed)

$0.149 \quad 0.000$

$$
\text { Pearson }
$$

0.411

$0.473^{* *}$

Correlation

Sig. (2-tailed)

$0.003 \quad 0.001$

Pearson

$\mathbf{0 . 5 4 7 * *} \quad 0.234$

Correlation

Sig. (2-tailed)

$0.000 \quad 0.102$

Pearson

$\mathbf{0 . 5 2 7}^{* *} \quad 0.277$

Correlation

Sig. (2-tailed)

$0.000 \quad 0.052$

Pearson

$\mathbf{0 . 3 8 0}^{* *} \quad 0.197$

Correlation

Sig. (2-tailed)

$0.006 \quad 0.171$

Pearson

$0.441 * *-0.020$

Correlation

Sig. (2-tailed)

$0.001 \quad 0.888$

Pearson

$\mathbf{0 . 5 0 7}^{* *} \quad 0.120$

Correlation

Sig. (2-tailed)

$0.000 \quad 0.408$

Pearson

$0.562 * * 0.430$

Correlation

Sig. (2-tailed)

$0.000 \quad 0.002$

Pearson

$0.456 * 0.476^{* *}$

Correlation

Sig. (2-tailed)

$0.001 \quad 0.000$

Pearson

$0.511^{* *} \quad 0.556^{* *}$

Correlation

Sig. (2-tailed)

$0.000 \quad 0.000$

(CPT) Alternative Fuels would be compatible with my Maritime needs

Pearson

$0.373^{* *} 0.325^{*}$

Correlation

Sig. (2-tailed)

$0.008 \quad 0.021$

(CPT) LGN is compatible with other systems/ services i use

Pearson

$-0.213$

$0.311^{*}$

Correlation

Sig. (2-tailed)

$0.138 \quad 0.028$

(CPT) Electricity is compatible with other systems/ services i use

Pearson

0.303* 0.133

Correlation

Sig. (2-tailed)

$0.033 \quad 0.357$

(CPT) Alternative Fuels are interoperable with other systems of existing vessels

Pearson

$0.691^{* *} 0.332^{*}$

Correlation

Sig. (2-tailed) $\quad 0.000 \quad 0.018$

CPX

Pearson

$-0.569^{* *}-0.261$

Correlation

Sig. (2-tailed) $\quad 0.000 \quad 0.067$

(CPX) I can understand the functions of Alternative Fuels and think that they are not complex

Pearson

$0.049 \quad 0.592$

Correlation

Sig. (2-tailed) $\quad 0.734 \quad 0.000$

(CPX) Alternative Fuels have refuel complexity

Pearson

$-\mathbf{0 . 4 4 6 * *}-0.597$ 
APPENDIX 1 - CORRELATIONS (Continued)

\begin{tabular}{|c|c|c|c|}
\hline & & PU & PEU \\
\hline & Correlation & & \\
\hline & Sig. (2-tailed) & 0.001 & 0.000 \\
\hline \multirow[t]{2}{*}{ (CPX) Diverse components within the system itself,results complexity } & $\begin{array}{l}\text { Pearson } \\
\text { Correlation }\end{array}$ & $-0.530^{* *}$ & -0.352 \\
\hline & Sig. (2-tailed) & 0.000 & 0.012 \\
\hline \multirow[t]{2}{*}{$\begin{array}{l}\text { (CPX) I think that fragmented decision-making landscape across global/na- } \\
\text { tional does not help inimplementation of Alternative Fuels }\end{array}$} & $\begin{array}{l}\text { Pearson } \\
\text { Correlation }\end{array}$ & $-0.566^{* *}$ & -0.146 \\
\hline & Sig. (2-tailed) & 0.000 & 0.311 \\
\hline \multirow[t]{2}{*}{ (CPX) Efficiency of Alternative Fuels is still at a low level } & $\begin{array}{l}\text { Pearson } \\
\text { Correlation }\end{array}$ & $-0.418^{* *}$ & -0.522 \\
\hline & Sig. (2-tailed) & 0.003 & 0.000 \\
\hline \multirow[t]{2}{*}{ SPR } & $\begin{array}{l}\text { Pearson } \\
\text { Correlation }\end{array}$ & $0.738^{* *}$ & -0.129 \\
\hline & Sig. (2-tailed) & 0.000 & 0.371 \\
\hline \multirow{2}{*}{$\begin{array}{l}\text { (SPR) A failure to properly address safety issues in the earliest stages of } \\
\text { development could influence the future development of these Alternative } \\
\text { fuels }\end{array}$} & $\begin{array}{l}\text { Pearson } \\
\text { Correlation }\end{array}$ & $0.346^{*}$ & -0.309 \\
\hline & Sig. (2-tailed) & 0.014 & 0.029 \\
\hline \multirow[t]{2}{*}{ (SPR) Hazard identification study is necessary } & $\begin{array}{l}\text { Pearson } \\
\text { Correlation }\end{array}$ & -0.165 & -0.274 \\
\hline & Sig. (2-tailed) & 0.253 & 0.055 \\
\hline \multirow[t]{2}{*}{ (SPR) I think using Alternative fuels has potential risk } & $\begin{array}{l}\text { Pearson } \\
\text { Correlation }\end{array}$ & 0.181 & -0.624 \\
\hline & Sig. (2-tailed) & 0.209 & 0.000 \\
\hline \multirow[t]{2}{*}{ (SPR) Concerns about extremely low temperatures of the LNG fuel } & $\begin{array}{l}\text { Pearson } \\
\text { Correlation }\end{array}$ & $0.670^{* *}$ & 0.082 \\
\hline & Sig. (2-tailed) & 0.000 & 0.571 \\
\hline \multirow[t]{2}{*}{ (SPR) I will feel safe to be on vessels fueled by alternative fuels } & $\begin{array}{l}\text { Pearson } \\
\text { Correlation }\end{array}$ & $0.539 * *$ & 0.644 \\
\hline & Sig. (2-tailed) & 0.000 & 0.000 \\
\hline \multirow[t]{2}{*}{ GP } & $\begin{array}{l}\text { Pearson } \\
\text { Correlation }\end{array}$ & 0.270 & $0.381^{* *}$ \\
\hline & Sig. (2-tailed) & 0.058 & 0.006 \\
\hline \multirow[t]{2}{*}{$\begin{array}{l}\text { (GP) Integration and adaptation of the international legal framework for } \\
\text { Alternative Fuels is necessary }\end{array}$} & $\begin{array}{l}\text { Pearson } \\
\text { Correlation }\end{array}$ & -0.039 & $0.469^{* *}$ \\
\hline & Sig. (2-tailed) & 0.790 & 0.001 \\
\hline \multirow[t]{2}{*}{ (GP) A long-term policy framework should favour Alternative Fuels } & $\begin{array}{l}\text { Pearson } \\
\text { Correlation }\end{array}$ & 0.665 & $0.297^{*}$ \\
\hline & Sig. (2-tailed) & 0.000 & 0.036 \\
\hline \multirow[t]{2}{*}{ (GP) Integrated strategies are required to ensure Alternative Fuels } & $\begin{array}{l}\text { Pearson } \\
\text { Correlation }\end{array}$ & 0.311 & $0.633^{* *}$ \\
\hline & Sig. (2-tailed) & 0.028 & 0.000 \\
\hline \multirow[t]{2}{*}{ (GP) A Regulatory timeline towards 2030 is needed } & $\begin{array}{l}\text { Pearson } \\
\text { Correlation }\end{array}$ & 0.156 & 0.141 \\
\hline & Sig. (2-tailed) & 0.280 & 0.327 \\
\hline \multirow[t]{2}{*}{$\begin{array}{l}\text { (GP) Policies need to encourage the further improvement of the fuel } \\
\text { efficiency }\end{array}$} & $\begin{array}{l}\text { Pearson } \\
\text { Correlation }\end{array}$ & -0.102 & $-0.306^{*}$ \\
\hline & Sig. (2-tailed) & 0.480 & 0.031 \\
\hline INF & Pearson & $-0.686^{* *}$ & 0.006 \\
\hline
\end{tabular}


APPENDIX 1 - CORRELATIONS (Continued)

\section{Correlations}

(I) Lack of Infrastructure can create barriers in the supply chain of
Alternative fuels
(I) I think consumers would be able to easily refuel their vehicles

(I) A common standardisation of the requirements for LNG supply infrastructure is needed

(I) Electrical infrastructure needs to accommodate all kinds of ports

(I) The infrastructure for cold ironing at marine terminals is wise

B\&E

(B\&E) Lack of guidelines for procedures for bunkering is a barrier

(B\&E) I think that an international standard for LNG bunkering should not be established

Correlation

PU

PEU

Correlation

Sig. (2-tailed)

$0.000 \quad 0.965$

Pearson

$-0.230-0.443$

Correlation

Sig. (2-tailed) $0.108 \quad 0.001$

$-0.707^{* *}-0.047$

Correlation

Sig. (2-tailed) $\quad 0.000 \quad 0.744$

Pearson

$-0.317^{*} \quad 0.102$

Correlation

Sig. (2-tailed) $\quad 0.025 \quad 0.480$

Pearson

$-0.248 \quad 0.303$

Correlation

Sig. (2-tailed) $0.082 \quad 0.032$

Pearson

$-0.361 * * 0.129$

Correlation

Sig. (2-tailed)

$0.010 \quad 0.372$

Pearson

$-0.400 * *-0.272$

Correlation

Sig. (2-tailed)

$0.004 \quad 0.056$

Pearson

$0.128-0.015$

Correlation

Sig. (2-tailed) $\quad 0.376 \quad 0.919$

Pearson

$-0.727^{* *}-0.049$

Correlation

Sig. (2-tailed) $\quad 0.000 \quad 0.734$

(B\&E) Developing battery technology will harbor ship applications potential

Pearson

$0.188-0.416$

Correlation

Sig. (2-tailed) $\quad 0.190 \quad 0.003$

$E \& F$

Pearson

$-0.404^{* *}-0.043$

Correlation

Sig. (2-tailed) $\quad 0.004 \quad 00.76$

(E\&F) Alternative Fuels lead to financial loss for me

Pearson

$-0.460 * * 0.281$

Correlation

Sig. (2-tailed) $\quad 0.001 \quad 0.048$

(E\&F) Alternative Fuels creates a positive budget

Pearson $0.008-0.445$

Correlation

Sig. (2-tailed) $\quad 0.958 \quad 0.001$

(E\&F) Alternative Fuels have higher operating costs

Pearson

$-0.420 * *-0.373$

Correlation

Sig. (2-tailed) $\quad 0.002 \quad 0.008$

(E\&F) I think that capital costs (infrastructure, new vessels) is a huge investment

Pearson

$-0.358^{*}-0.406$

Correlation

Sig. (2-tailed) $0.011 \quad 0.003$

(E\&F) The initial investment required (propulsion systems, fuel handling systems) is enormous

Pearson

$0.092 \quad 0.419$

Correlation

Sig. (2-tailed) $0.525 \quad 0.002$ 
APPENDIX 1 - CORRELATIONS (Continued)

\section{Correlations}

(PR) Ports can set rules, addressing specific operational aspects
(PR) Port Authorities should support the deployment of Alternati
for shipping
(PR) Port Services should be flexible to interact with international
guidelines of Alternative fuels

(PR) Alternative fuels should be incorporated by the Port Authorities.

TC

(TC) A platform for addressing technical issues is still in its infancy

(TC) Concerns about space limitations (larger tanks)

(TC) Concerns about ship design issues to the existing vessels

(TC) Fuel cell Technology for ships is still in its infancy

(TC) Alternative Fuels might not perform well and create problems

(TC) I am worried about technological system failures

AVL

$(\mathrm{AVL})$ There is a limited production capacity of these Alternative Fuels

(AVL) I think Alternative Fuels will have poor stability

(AVL) Limited Availability (chicken-and-egg problem) is worrying

(AVL) If Alternative Fuels become so attractive, will not be available in

\begin{tabular}{|c|c|c|}
\hline & PU & PEU \\
\hline \multicolumn{3}{|l|}{ Correlation } \\
\hline Sig. (2-tailed) & 0.039 & 0.000 \\
\hline $\begin{array}{l}\text { Pearson } \\
\text { Correlation }\end{array}$ & 0.363 & $0.695^{* *}$ \\
\hline Sig. (2-tailed) & 0.010 & 0.000 \\
\hline $\begin{array}{l}\text { Pearson } \\
\text { Correlation }\end{array}$ & 0.196 & 0.087 \\
\hline Sig. (2-tailed) & 0.173 & 0.547 \\
\hline $\begin{array}{l}\text { Pearson } \\
\text { Correlation }\end{array}$ & 0.392 & $0.651^{* *}$ \\
\hline Sig. (2-tailed) & 0.005 & 0.000 \\
\hline $\begin{array}{l}\text { Pearson } \\
\text { Correlation }\end{array}$ & -0.185 & -0.233 \\
\hline Sig. (2-tailed) & 0.198 & 0.103 \\
\hline $\begin{array}{l}\text { Pearson } \\
\text { Correlation }\end{array}$ & $-0.846^{* *}$ & $\overline{0.321^{*}}$ \\
\hline Sig. (2-tailed) & 0.000 & 0.023 \\
\hline $\begin{array}{l}\text { Pearson } \\
\text { Correlation }\end{array}$ & $-0.725^{* *}$ & -0.169 \\
\hline Sig. (2-tailed) & 0.000 & 0.239 \\
\hline $\begin{array}{l}\text { Pearson } \\
\text { Correlation }\end{array}$ & $-0.712^{* *}$ & -0.435 \\
\hline Sig. (2-tailed) & 0.000 & 0.002 \\
\hline $\begin{array}{l}\text { Pearson } \\
\text { Correlation }\end{array}$ & $-0.609 * *$ & 0.000 \\
\hline Sig. (2-tailed) & 0.000 & 10.000 \\
\hline $\begin{array}{l}\text { Pearson } \\
\text { Correlation }\end{array}$ & $-0.606^{* *}$ & -0.358 \\
\hline Sig. (2-tailed) & 0.000 & 0.011 \\
\hline $\begin{array}{l}\text { Pearson } \\
\text { Correlation }\end{array}$ & $-0.794^{* *}$ & -0.266 \\
\hline Sig. (2-tailed) & 0.000 & 0.062 \\
\hline $\begin{array}{l}\text { Pearson } \\
\text { Correlation }\end{array}$ & $-0.764^{* *}$ & -0.429 \\
\hline Sig. (2-tailed) & 0.000 & 0.002 \\
\hline $\begin{array}{l}\text { Pearson } \\
\text { Correlation }\end{array}$ & $-0.738^{* *}$ & -0.123 \\
\hline Sig. (2-tailed) & 0.000 & 0.394 \\
\hline $\begin{array}{l}\text { Pearson } \\
\text { Correlation }\end{array}$ & $-0.691^{* *}$ & -0.076 \\
\hline Sig. (2-tailed) & 0.000 & 0.599 \\
\hline $\begin{array}{l}\text { Pearson } \\
\text { Correlation }\end{array}$ & $-0.743^{* *}$ & -0.225 \\
\hline Sig. (2-tailed) & 0.000 & 0.116 \\
\hline $\begin{array}{l}\text { Pearson } \\
\text { Correlation }\end{array}$ & $-0.492^{* *}$ & 0.186 \\
\hline Sig. (2-tailed) & 0.000 & 0.195 \\
\hline Pearson & $-0.630^{* *}$ & -0.130 \\
\hline
\end{tabular}


APPENDIX 1 - CORRELATIONS (Continued)

\begin{tabular}{|c|c|c|c|}
\hline & & PU & PEU \\
\hline \multirow[t]{2}{*}{ sufficient quality } & Correlation & & \\
\hline & Sig. (2-tailed) & 0.000 & 0.369 \\
\hline \multirow[t]{2}{*}{ (AVL) There are gaps regarding quality standards for Alternative Fuels } & $\begin{array}{l}\text { Pearson } \\
\text { Correlation }\end{array}$ & $-0.623 * *$ & -0.289 \\
\hline & Sig. (2-tailed) & 0.000 & 0.042 \\
\hline \multirow[t]{2}{*}{ PT } & $\begin{array}{l}\text { Pearson } \\
\text { Correlation }\end{array}$ & 0.116 & 0.278 \\
\hline & Sig. (2-tailed) & 0.423 & 0.051 \\
\hline \multirow[t]{2}{*}{ (PT) Concerns about possible resistance to infrastructure } & $\begin{array}{l}\text { Pearson } \\
\text { Correlation }\end{array}$ & -0.305 & 0.384 \\
\hline & Sig. (2-tailed) & 0.031 & 0.006 \\
\hline \multirow[t]{2}{*}{ (PT) Alternative fuels perform well relative to sustainability } & $\begin{array}{l}\text { Pearson } \\
\text { Correlation }\end{array}$ & -0.440 & -0.003 \\
\hline & Sig. (2-tailed) & 0.001 & 0.985 \\
\hline \multirow[t]{2}{*}{ (PT) There is a great deal of uncertainty with the use of alternative fuels } & $\begin{array}{l}\text { Pearson } \\
\text { Correlation }\end{array}$ & 0.821 & 0.035 \\
\hline & Sig. (2-tailed) & 0.000 & 0.810 \\
\hline \multirow[t]{2}{*}{ (PT) I am against using alternative fuels } & $\begin{array}{l}\text { Pearson } \\
\text { Correlation }\end{array}$ & -0.009 & 0.147 \\
\hline & Sig. (2-tailed) & 0.953 & 0.308 \\
\hline \multirow[t]{2}{*}{ (PT) Overall, i can trust Alternative Fuels } & $\begin{array}{l}\text { Pearson } \\
\text { Correlation }\end{array}$ & 0.745 & 0.036 \\
\hline & Sig. (2-tailed) & 0.000 & 0.806 \\
\hline \multirow[t]{2}{*}{ PU } & $\begin{array}{l}\text { Pearson } \\
\text { Correlation }\end{array}$ & 1 & $0.434^{* *}$ \\
\hline & Sig. (2-tailed) & & 0.002 \\
\hline \multirow[t]{2}{*}{ (PU) The development of Alternative Fuels is a waste of resources } & $\begin{array}{l}\text { Pearson } \\
\text { Correlation }\end{array}$ & -0.051 & $0.304^{*}$ \\
\hline & Sig. (2-tailed) & 0.722 & 0.032 \\
\hline \multirow[t]{2}{*}{ (PU) Using Alternative Fuels will improve the company's performance } & $\begin{array}{l}\text { Pearson } \\
\text { Correlation }\end{array}$ & 0.843 & $0.425^{* *}$ \\
\hline & Sig. (2-tailed) & 0.000 & 0.002 \\
\hline \multirow[t]{2}{*}{ (PU) Using Alternative Fuels will increase company's productivity } & $\begin{array}{l}\text { Pearson } \\
\text { Correlation }\end{array}$ & 0.838 & $0.353^{*}$ \\
\hline & Sig. (2-tailed) & 0.000 & 0.012 \\
\hline \multirow[t]{2}{*}{ (PU) Overall, I find the technology transition to Alternative Fuels useful } & $\begin{array}{l}\text { Pearson } \\
\text { Correlation }\end{array}$ & 0.851 & $0.346^{*}$ \\
\hline & Sig. (2-tailed) & 0.000 & 0.014 \\
\hline \multirow[t]{2}{*}{ PEU } & $\begin{array}{l}\text { Pearson } \\
\text { Correlation }\end{array}$ & $0.434^{* *}$ & 1 \\
\hline & Sig. (2-tailed) & 0.002 & \\
\hline \multirow[t]{2}{*}{$\begin{array}{l}\text { (PEU) Learning to operate/work vessels fuelled with Alternative Fuels will } \\
\text { be easy }\end{array}$} & $\begin{array}{l}\text { Pearson } \\
\text { Correlation }\end{array}$ & $0.511^{* *}$ & 0.698 \\
\hline & Sig. (2-tailed) & 0.000 & 0.000 \\
\hline \multirow[t]{2}{*}{ (PEU) I think becoming skillful at using Alternative Fuels is easy } & $\begin{array}{l}\text { Pearson } \\
\text { Correlation }\end{array}$ & $0.307^{*}$ & 0.859 \\
\hline & Sig. (2-tailed) & 0.030 & 0.000 \\
\hline (PEU) Interacting with Alternative Fuels would not require a lot of mental & Pearson & -0.001 & 0.813 \\
\hline
\end{tabular}


APPENDIX 1 - CORRELATIONS (Continued)

\begin{tabular}{|c|c|c|c|}
\hline \multicolumn{4}{|l|}{ Correlations } \\
\hline & & PU & PEU \\
\hline \multirow[t]{2}{*}{ effort } & Correlation & & \\
\hline & Sig. (2-tailed) & 0.993 & 0.000 \\
\hline \multirow[t]{2}{*}{ (PEU) Overall, I find it useful to adopt Alternative Fuels } & $\begin{array}{l}\text { Pearson } \\
\text { Correlation }\end{array}$ & $0.443^{* *}$ & 0.580 \\
\hline & Sig. (2-tailed) &, 001 &, 000 \\
\hline
\end{tabular}

\section{Acknowledgements}

We thank Journal of Shipping and Trade for accepting this Special Issue and conference "2021 World of Shipping Portugal-In the Aftermath of 2020!What's next?" for covering this Special Issue process charges.

\section{Authors' contributions}

OS is the corresponding author. MP and NN contributed to the research methodology and NN has also carried out the final evaluation. TL contributed to the theoretical background. DP contributed to data analysis and results. All authors read and approved the final manuscript.

\section{Authors' information}

Olga Sideri, Researcher in HPD Innovation Lab. Olga holds a MSC in the Department of History and Philosophy of Science and Technology (HPST) with a specialisation in the Science and Technology Studies (STS) at the National and Kapodistrian University of Athens and the National Technical University. Her dissertation was "Liquefied Natural Gas (LNG) as marine Fuel: Policies and the Quest for Sustainable Shipping in Greece". Olga is also a postgraduate student (MSc) in the Department of "New technologies in Shipping and Transport" at the University of Aegean with the Department of "Automation Engineering" at the University of West Attica. Olga has been awarded the scholarship of the Hellenic Shortsea Shipowners Association for the year 2017-2018. She is particularly interested in the innovative technological transitions towards green shipping and towards sustainable development. She has worked intensively with the Hellenic Institute of Marine Technology (H.I.M.T.) for the last 3 years.

Michalis Papoutsidakis, Associate Professor, University of West Attica, Dept. of Industrial Design and Production Eng., Director of the postgraduate program "New technologies in shipping and transport". His research interests include industrial automation, marine automation, robotics, management technology and innovation.

Theodore Lilas, Assistant Professor at the Department of Shipping, Trade and Transport, University of the Aegean. Phd in Electrical Engineering. His research interests include Information technology (IT), computer programming, software development, green shipping.

Nikitas Nikitakos, Professor, Dept. Shipping, Transportation and Trade, University of Aegean and Director of Informatics and New Technologies in Shipping, Transport and Insular Development Lab (LINTSTID). His research interests are green shipping, shipping IT, innovation, project management, shipping etc.

Dimitrios Papachristos, Lecturer, Dept. Industrial Design and Production, University of West Attica. His research interests are human-computer interaction, green shipping, shipping IT, etc.

\section{Funding}

Not Applicable.

\section{Availability of data and materials}

The datasets generated and/or analysed during the current study are not publicly available due to individual privacy but are available from the corresponding author on reasonable request.

\section{Declaration}

\section{Competing interests}

The authors declare that they have no competing interests.

\section{Author details}

'University of West Attica, Egaleo 12241, Greece. ${ }^{2}$ University of the Aegean, Chios 82100, Greece.

Received: 16 March 2021 Accepted: 11 May 2021

Published online: 13 July 2021

\section{References}

Ajzen I (1985) From Intentions to Actions: A Theory of Planned Behavior. In: Kuhl J., Beckmann J. (eds) Action Control. SSSP Springer Series in Social Psychology. Springer, Berlin, Heidelberg.

Al-Ghaith W (2015) Applying the technology acceptance model to understand social networking sites (SNS) usage: impact of perceived social capital. Int J Comp Sci Inform Technol 7:4

American Bureau of Shipping (ABS) (2018). Guide for LNG bunkering. ABS Plaza. Houston, USA

Bandura A (1986) Social Foundations of Thought and Action: A Social Cognitive Theory. Englewood Cliffs, NJ: Prentice- Hall Inc. 
Carter L, Bélanger F (2005) The utilization of E-government services: citizen trust, innovation and acceptance factors. Inf Syst J 15(1):5-25. https://doi.org/10.1111/j.1365-2575.2005.00183.x

Chang SC, Tung FC (2008) An empirical investigation of students' behavioural intentions to use online learning course websites. Br J Educ Technol 39(1):71-83

Chau YK, Hu JH (2001) Information technology acceptance by individual professionals: a model comparison approach. Decis Sci 32(4):669-719

Davis F, Bagozzi R, Warshaw P (1992). Extrinsic and Intrinsic Motivation to Use Computers in the Workplace. J Appl Soc Psychol, 22(14), 1111-1132

Davis FD (1989) Perceived usefulness, perceived ease of use, and user acceptance of information technology. MIS Q 13(3): 319-340.https://doi.org/10.2307/249008.

Det Norske Veritas and Germanischer Lloyd (DNV-GL). (2014). LNG as ship fuel. G.-M. Wuersig, A. Chiotopoulos, S. Adams (eds), No01,https://www.dnv.com/Images/LNG_report_2015-01_web_tcm8-13833.pdf

Det Norske Veritas and Germanischer Lloyd (DNV-GL). (2018). LNG regulatory update, "Best fuel of the future", conference \& study tour, updated 1 April

European Alternative Fuels Observatory (EAFO), n.d.. Alternative Fuels used for Shipping. URL: https://www.eafo.eu/shippingtransport/shipping-overview/affor-shipping. Accessed 27 Nov 2020.

European Commission, innovation and networks executive agency (INEA), 2011. EU-21007-S, COSTA. URL: https:/ec.europa. eu/inea/en/ten-t/ten-t-projects/projects-by-country/multi-country/2011-eu-21007-s [Accessed 5 Dec 2020]

European Community Shipowner's Associations (ECSA) (2017) Shipping and global trade. Towards an EU external shipping policy, ECSA

Fagerberg J, Martin BR, et al (2013) Innovation studies - evolution and future challenges. https://doi.org/10.1093/acprof:oso/ 9780199686346.001 .0001

Fishbein M, Ajzen I (1975) Belief, Attitude, Intention and Behavior: An Introduction to Theory and Research. Reading, MA: Addison-Wesey

International Maritime Organization (IMO) (n.d.) Sulphur 2020 - cutting sulphur oxide emissions. IMO URL: https://www.imo. org/en/MediaCentre/HotTopics/Pages/Sulphur-2020.aspx. Accessed 15 Dec 2020

Karahanna E, Straub D, Chervany NL (1999) Information technology adoption across time: a cross-sectional comparison of pre-adoption and post-adoption beliefs

Lee I, Park J, Moon I (2017). Key Issues and Challenges on the Liquefied Natural Gas (LNG) Value Chain: A Review from the Process Systems Engineering Point-of-View. Industrial \& Engineering Chemistry Research 2018:57(17):5805-5818

Lee YH, Hsieh YC, Hsu CN (2011) Adding innovation diffusion theory to the technology acceptance model: supporting employees' intentions to use E-learning systems. Educ Technol Soc 14(4):124-137

Legris P, Ingham J, Collerette P (2003) Why do people use information technology? A critical review of the technology acceptance model. Inform Manag 40(Issue 3):191-204

Lou TF, Li EY (2017) Integrating innovation diffusion theory and the technology acceptance model: the adoption of blockchain technology from business managers' perspective. In: Proceedings of the 17th international conference on electronic business. ICEB, Dubai, pp 293-296

Mitrou P (2018). Electrification in ports and vessels: Towards sustainable sea mobility. Lloyd's Register. 3rd international conference Ports, Maritime Transport \& Insularity. Piraeus Chamber of Commerce \& Industry19 \& 20 April 2018. https:// smartports.gr/wp-content/uploads/2018/05/MITROU-Electrification-in-Ports-Vessels.pdf

Mokhatab S, Mak JY, Valappil J, Wood DA (2014). Handbook of Liquefied Natural Gas. Elsevier (January 2014)

Momani AM, Mamoun JM 2017. The Evolution of Technology Acceptance Theories, Int J Contemp Comp Res. 1(1):

Rogers EM (1995) Diffusion of innovations, 4th edn. Free Press, New York

Rogers EM (2003) Diffusion of innovations, 3rd edn. The Free Press, New York

Shih CH (2007) Integrating innovation diffusion theory and UTAUT to explore the influencing factors on teacher adopt Elearning system - with MOODLE as an example. Unpublished Master Thesis, Dayeh University (Changhua County, Taiwan)

Sigala M, Airey D, Jones P, Lockwood A (2000) The diffusion and application of multimedia technologies in the tourism and hospitality industries. In: Information and communication Technologies in Tourism 2000. Springer, Vienna, pp 396-407. https://doi.org/10.1007/978-3-7091-6291-0_36

Sivo SA, Ku CH et al (2018) Understanding how university student perceptions of resources affect technology acceptance in online learning courses. Aust J Educ Technol 34(4):74

Sung YP (2009) An analysis of the technology acceptance model in Understanding University students' behavioral intention to use e-learning, park, S. Y. (2009), p. 151, an analysis of the technology acceptance model in Understanding University students' behavioral intention to use e-learning. Educ Technol Soc 12(3):150-162

Surendran P (2012) Technology acceptance model: a survey of literature. Int J Business Soc Res 2:4

Sykes T, Venkatesh V, Gosain S (2009). Model of Acceptance with Peer Support: A Social Network Perspective to Understand Employees' System Use. MIS Quarterly, 33(2): 371-393

Tornatzky LG, Klein KJ (1982) Innovation characteristics and innovation adoption implementation: a meta-analysis of findings. IEEE Trans Eng Manag 29(1):28-45

Thompson R, Higgins C, Howell J (1991). Personal Computing: Toward a Conceptual Model of Utilization. MIS Quarterly, 15(1): $125-143$

Tzannatos E, Nikitakos N (2013) Natural gas as a fuel alternative for sustainable domestic passenger shipping in Greece. Int J Sustain Energy 32(6)::724-734. https://doi.org/10.1080/14786451.2013.811414

Van Slyke C, Belanger F, Comunale C (2004) Factors influencing the adoption of web-based shopping: the impact of trust. In: Database for Advances in Information Systems

Verbeek R., G. Kodijk et al., 2011. Environmental and economic aspects of using LNG as a fuel for shipping in the Netherlands, TNO report

Venkatesh V, Davis FD (2000) A Theoretical Extension of Technology Acceptance Model: Four Longitudinal Field Studies. Management Science, 46(2):186-204 
Venkatesh V, Morris MG, Davis GB, Davis FD (2003) User acceptance of information technology: toward a unified view. MIS Q 27(3):425-478. https://doi.org/10.2307/30036540

Wang S, Notteboom T (2014) The adoption of liquefied natural gas as a ship fuel: a systematic review of perspectives and challenges. Transport Rev 34:6 749-774, 756

Wu JH, Wang SC (2005) What drives mobile commerce? An empirical evaluation of the revised technology acceptance model. Inf Manag 42(5):719-729. https://doi.org/10.1016/j.im.2004.07.001

Yang MM (2007) An exploratory study on consumers' behavioral intention of usage of third generation mobile value-added services. Unpublished Master Thesis, National Cheng Kung University (Tainan City, Taiwan)

\section{Publisher's Note}

Springer Nature remains neutral with regard to jurisdictional claims in published maps and institutional affiliations.

Submit your manuscript to a SpringerOpen ${ }^{\circ}$ journal and benefit from:

- Convenient online submission

- Rigorous peer review

- Open access: articles freely available online

- High visibility within the field

- Retaining the copyright to your article

Submit your next manuscript at $\boldsymbol{\nabla}$ springeropen.com 